\title{
Model Pelayanan Pastoral Konseling terhadap Orang Sakit berdasarkan Lukas 10:33-35
}

\author{
Sori Tjandrah Simbolon
}

\begin{abstract}
Abstrak
Pelayanan pastoral konseling terhadap orang sakit adalah pelayanan yang memperlengkapi pelayanan yang selama ini dilakukan oleh para petugas kesehatan dan petugas lainnya yang ingin menolong para pasien mengalami kesembuhan. Pelayanan pastoral konseling berbeda dengan pelayanan lainnya secara umum, karena pelayanan ini bukan hanya menekankan pada penyembuhan secara fisik saja tetapi pelayanan yang meyentuh seluruh aspek kehidupan manusia, baik secara fisik, jiwa dan roh/spiritualnya. Pelayanan ini menekankan pada pelayanan agar manusia saat mengalami sakit dapat memahami rencana Allah dalam hidupnya, dan bahkan mereka dapat menerima rasa sakit sebagai alat bagi perubahan paradigma dan mampu memperbaiki perilaku mereka agar mereka menjadi pribadi yang lebih baik dan lebih sehat.
\end{abstract}

Kata Kunci: Pastoral, konseling, kesehatan, sakit, kesembuhan, penyakit

\begin{abstract}
Pastoral counseling services for the sick are services that complement the services that have been carried out by health workers and other officers who want to help patients experience healing. Pastoral counseling services are different from other services in general, because these services not only emphasize physical healing but services that touch all aspects of human life, both physically, mentally and spiritually. This ministry emphasizes service so that people when they are experiencing pain can understand God's plan in their lives, and they can even accept pain as a tool for paradigm change and be able to improve their behavior so that they become better and healthier individuals.
\end{abstract}

Keywords: Pastoral, counseling, health, illness, healing, illness

\section{Pengertian Pelayanan Pastoral Konseling}

Istilah pelayanan pastoral konseling adalah gabungan dari pelayanan pastoral dan pelayanan konseling. Meski istilah "pelayanan pastoral" bagi masyarakat umum di Indonesia belum populer dan masih terdengar asing, istilah ini memang diadopsi ke dalam bahasa Indonesia dari budaya dan bahasa yang berbeda yaitu dari budaya barat dengan bahasa Inggrisnya dan juga dari akar atau pemahaman tentang teologi Kristen, jelas hal ini kurang banyak dipahami karena masih belum memasuki budaya umum dari mayoritas masyarakat di Indonesia. 
Istilah "Pastoral" sendiri berasal dari kata "Pastor" atau "Pastorate" yang berarti Pelayan yang ditahbiskan sehingga disebut Pendeta atau Gembala Sidang. ${ }^{1}$ Juga dikemukakan dalam Kamus Teologi karangan Collins dan Farrugia bahwa istilah Pastor digunakan di dalam lingkungan orang-orang Protestan dan orang-orang Katholik di beberapa daerah di Jerman, Pastor digunakan untuk para pelayan tertahbis yang melayani gereja lokal. Istilah ini diambil dari Alkitab seperti yang mereka katakan sebagai berikut: ${ }^{2}$

"Pastor dalam Perjanjian Lama dikenakan kepada para pemimpin (Yer 2:8; 3:15) dan dikenakan juga pada Allah sebagai gembala yang baik (Yeh 34:1-31; Maz 23). Kristus diutus kepada dombadomba Israel yang hilang (Mat 10:6; 15:24; lih. Luk 15:3-7). Sebagai gembala yang baik, Ia menyerahkan hidupnya bagi domba-dombanya (Yoh 10:11-16; lih. Ibr 13:20; 1 Ptr 2:25). Ia memanggil orang lain untuk menjadi gembala dalam Gereja, tetapi umat tetaplah domba-dombaNya (Yoh 21:15-17; 1 Ptr 5:1-4).“ (O’Collins \& Faruggia, 1996:32)

Pada mulanya, istilah Pastor ini adalah istilah dari Alkitab yang berarti pemimpin atau gembala yang menyerahkan hidupnya bagi domba-dombanya maka, istilah Pastor tersebut menjadi sangat populer dan sampai saat ini terus dipergunakan terutama di lingkungan gereja-gereja Protestan. Pastor dalam bahasa Indonesia sering disebut juga Pendeta atau Gembala Sidang, sedangkan istilah pastoral sendiri bisa disebut hal yang menyangkut pendetaan atau pengembalaan, seperti yang dikatakan pula dalam Kamus Besar Bahasa Indonesia. ${ }^{3}$

Pelayanan pastoral adalah suatu pelayanan yang pada umumnya sering kali diindentikkan dengan pelayanan yang berhubungan dengan ruang lingkup di gereja saja, padahal sebenarnya cakupan pelayanan pastoral bukan hanya untuk kepentingan di ruang lingkup gereja saja, tetapi bisa juga menjangkau pelayanan yang lebih luas dari sekedar pelayanan gerejawi, yaitu pelayanan yang ditujukan untuk kebutuhankebutuhan manusia atau masyarakat pada umumnya yang berada di luar ruang lingkup gerejawi misalnya pelayanan pastoral di dalam berbagai bidang seperti: Pendidikan, sosial, politik, budaya, kesenian, keamanan, pekerjaan, kesehatan dan banyak bidangbidang lainnya.

\footnotetext{
${ }^{1}$ Yayasan Kristen untuk Kesehatan Umum (Ed.), Mendampingi Dengan Hati: Modul Pendampingan Pastoral, (Surakarta: Yakkum Press, 2008), p.ix

${ }^{2}$ Gerald O’Collins dan Edward G. Farrugia, Kamus Teologi. (Yogyakarta: Penerbit Kanisius 1996), 232.

${ }^{3} \mathrm{KBBI}$; diambil dari: https://kbbi.web.id/pastoral; internet; diakses 10 Mei 2020.
} 
Pembahasan mengenai ruang lingkup pelayanan pastoral yang bukan hanya untuk lingkungan gerejawi salah satunya pernah diungkapkan oleh seorang tokoh pelayanan pastoral di Indonesia, yang bernama Daniel Susanto, di dalam bukunya yang berjudul "Pelayanan Pastoral di Indonesia", beliau menyatakan bahwa pelayanan pastoral meliputi banyak aspek atau hal, pernyataan beliau adalah sebagai berikut ini: Paling utama tentunya pelayanan pastoral dipergunakan untuk gereja-gereja, lalu pelayanan pastoral mencakup juga pelayanan pastoral untuk bimbingan pra-nikah, untuk korban kekerasan di dalam keluarga atau rumah tangga, untuk kaum remaja yang mengalami kekerasan, untuk kaum lansia (lanjut usia), untuk para mahasiswa, untuk para pengusaha, untuk memperlengkapi para pelayan pastoral atau pendeta itu sendiri (pendidikan teologia), pelayanan pastoral di rumah-rumah sakit, pelayanan pastoral khusus untuk penderita/pasien kanker atau terminal illness, dimana para pasien secara medis diprediksi (prognosa) akan mengalami meninggal atau mengalami kematian. Lalu pelayanan pastoral untuk orang-orang miskin dan terlantar, untuk kaum buruh perempuan dan untuk pekerja-pekerja migran. ${ }^{4}$

Sementara itu, seorang penulis tentang pelayanan pastoral yang lain, yaitu R.E.O. White menjelaskan juga mengenai banyaknya ruang lingkup pelayanan pastoral, walaupun hal-hal utamanya jelas diperuntukkan bagi pelayanan di gereja, namun banyak juga menyentuh berbagai aspek atau bidang lain seperti keluarga, hubungan antar manusia, kesehatan dan lainnya. Di dalam bukunya A Guide to Pastoral Care, ia menjelaskan bahwa tugas-tugas pelayan pastoral meliputi berbagai bidang seperti berikut ini: Pelayanan Pastoral dalam bidang ibadah, kepemimpinan, kunjungan atau visitasi, konseling, pernikahan, perkabungan, penginjilan, hubungan orang tua dan anak, kaum muda yang mengalami kesulitan, permasalahan di dalam rumah tangga, pelayanan terhadap orang sakit, persoalan usia, persoalan menghadapi kematian, kesulitan dalam hal seksualitas, kecanduan, juga hal-hal lain seperti pastoral psikologi, permasalahan moralitas dan terapinya, persoalan-persoalan mental dan terapinya, juga permasalahanpermasalahan yang berhubungan gangguan emosi dan lain-lain. ${ }^{5}$

${ }^{4}$ Daniel Susanto (Ed.), Sekilas Tentang Pelayanan Pastoral di Indonesia: Buku Kenag-kenangan 30 tahun Pelayanan Pendeta Daniel Susanto selaku Pendeta GKI dengan Basis Pelayanan di GKI Menteng Jakarta (6 Juni 1978- 6 Juni 2008). (Jakarta: Penerbit Majelis Jemaat GKI Menteng Jakarta, 2008), p.iii-iv.

${ }^{5}$ R.E.O White, A Guide to Pastoral Care: A Practical Primer of Pastoral Theology. (Glasgow: Pickering \& Inglis LTD, 1976), v-vii. 
Pelayanan pastoral saat ini sudah memiliki cakupan yang sangat luas, seluas kehidupan manusia itu sendiri; para pelayan pastoral diharapkan mampu membantu masyarakat luas sesama manusia dalam menghadapi berbagai kasus dalam kehidupan manusia. ${ }^{6}$

Seperti diungkapkan di atas bahwa pelayanan pastoral ruang lingkupnya sudah sedemikian luasnya seiring dengan kebutuhan manusia dalam menyelesaikan problematika kehidupannya. Khususnya untuk penanganan masalah-masalah yang berhubungan kejiwaan manusia mulai dari masalah pribadi, keluarga, pekerjaan, relasi, perilaku buruk, sakit, penyakit, maka lahirlah pendekatan yang menggabungkan atau mengintegrasikan pelayanan pastoral yang berasal dari ilmu teologi dengan ilmu psikologi khususnya di dalam bidang konseling. Mengingat luasanya cakupan ilmu psikologi dan dikarenakan adanya beberapa pandangan dari psikologi yang terlalu menekankan terlalu banyak pada sudut humanisme, sehingga seringkali mengabaikan unsur-unsur rohani, seperti mengabaikannya aspek dosa dalam pendekatan psikologinya, maka tentunya tidak semua pendekatan ilmu psikologi dapat digunakan begitu saja. Sebagai acuan dari pelayanan pastoral konseling tetaplah menggunakan Alkitab sebagai Pedoman Utama dalam kehidupan umat manusia, terutama dalam konteks penyelesaian masalah-masalah kemanusiaan. ${ }^{7}$

Dalam konteks penyelesaian untuk pelayanan kesehatan bagi orang-orang sakit, selama ini yang memegang peranan penting adalah tenaga kesehatan seperti dokter, perawat, dan tenaga kesehatan lainnya, tetapi pada kenyataannya di lapangan khususnya di rumah-rumah sakit, seringkali ditemukan adanya penyakit yang diakibatkan oleh faktor-faktor kejiwaan seseorang yang seringkali distilahkan psikosomatis. Penyakit yang diakibatkan oleh faktor kejiwaan/psikis seringkali tidak dapat tertangani dengan baik oleh para petugas kesehatan, walaupun terdapat jenis pelayanan kesehatan untuk permasalan psikis ini yaitu pelayanan melalui kedokteran kejiwaan yang dikenal dengan istilah psikiater atau dokter spesialis kesehatan jiwa (SpKJ).

${ }^{6}$ Billy Graham Counseling Department, Buku Pegangan Pelayanan: Prinsip, Langkah dan Cara Mengatasi Masalah Dalam Penginjilan dan Bimbingan Pribadi. (Jakarta: Persekutuan Pembaca Alkitab, 1984), p.iii-V ${ }^{7}$ Yastoral....., p.x 
Pada kenyataannya, perlu ada tambahan pelayanan yang dapat membantu penyelesaian masalah para pasien dengan pendekatan spiritual, penguatan spiritual yang membantu para pasien untuk memahami makna kehidupan secara komprehensif dan utuh, tentunya penguatan spiritual akan membantu para pasien dalam menjalani prose penyembuhan di rumah sakit. Di sinilah peran konseling pastoral sangat dibutuhkan dikarenakan menggunakan pendekatan psiko spiritual.

Seperti telah dikatakan di atas, untuk pelayanan kepada orang-orang sakit selain para dokter dan perawat serta tenaga medis, seringkali dibutuhkan juga bantuan dari pelayan pastoral konseling karena seringkali mereka yang mengalami sakit perlu penguatan dalam menjalani proses penyembuhan mereka, bahkan pelayanan inipun bisa berkembang untuk membantu keluarga pasien terutama saat penyakit yang dialami sangat berat bahkan bisa membawa pada kematian. Seringkali dijumpai penyakit yang diderita para pasien di rumah sakit dikarenakan karena faktor pikiran, kecemasan, stress, dan tekanan kejiwaan lainnya atau psikis yang disebut dengan psikosomatis. Dikarenakan pelayanan pastoral konseling digunakan untuk menolong orang sakit maka, sebelum membahas lebih lanjut tentang pelayanan pastoral konseling perlu dibahas tentang hal-hal mengenai penyakit dan sakit.

\section{Pengertian Sakit Dan Penyakit}

Pembahasan mengenai pengertian sakit adalah hal yang penting dalam pelayanan pastoral konseling terhadap orang sakit atau pasien. Sakit adalah perasaan yang dialami oleh manusia sebagai penderita akibat yang ditimbulkan oleh penyakit. Maka pengertian sakit dan penyakit seringkali muncul bergantian namun bagi penulis tidak terlalu membedakan keduanya, karena kedua pengertian tersebut saling berkaitan erat satu sama lain. Sedangkan usaha manusia untuk mengalami penyembuhan atau pengobatan bagi rasa sakit dan penyakit adalah suatu bentuk usaha agar manusia memperoleh kondisi yang sehat dan sejahtera.

Menurut Kamus Besar Bahasa Indonesia (KBBI), pengertian sakit adalah berasa tidak nyaman di tubuh atau bagian tubuh karena menderita sesuatu (demam, sakit perut, dan sebagainya). Sedangkan pengertian penyakit adalah: 1 . Sesuatu yang menyebabkan terjadinya gangguan pada makhluk hidup; 2 . Gangguan kesehatan yang disebabkan oleh 
bakteri, virus, atau kelainan sistem faal atau jaringan pada organ tubuh (pada makhluk hidup); dan yang ke-3. Kebiasaan yang buruk; sesuatu yang mendatangkan keburukan. 8 Kamus terkenal dalam bahasa Inggris, Merriam-Webster, mendefinisikan sakit sebagai sebuah kondisi tidak sehat baik tubuh dan pikiran kita, atau tubuh dan pikiran kita tidak dapat bekerja dengan normal. ${ }^{9}$

Mengenai pengertian tentang penyakit, seorang dokter bernama Irwan, seorang ahli kesehatan masyarakat memberikan pernyataan seperti di bawah ini: ${ }^{10}$

Penyakit atau disease dapat diartikan sebagai gangguan fungsi suatu organisme sebagai akibat dari infeksi atau tekanan dari lingkungan. Karena itu penyakit bersifat objektif. Hal ini berbeda dengan sakit atau illness, yaitu penilaian individu terhadap pengalaman menderita suatu penyakit. (Irwan, 2016).

Azrul Azwar mengemukakan bahwa penyakit adalah suatu kondisi abnormal dari tubuh dan pikiran seseorang sehingga membuatnya tidak nyaman, mengalami kesukaran dan disfungsi. ${ }^{11}$

\section{Sejarah Singkat Mengenai Penyakit dan Pengobatannya}

Pemahaman tentang penyakit sangatlah panjang sejarahnya, sepanjang sejarah keberadaan atau kehidupan manusia di permukaan bumi ini. Dalam bukunya yang berjudul A History of Medicine, Lois N. Magner dan Oliver J. Kim membahas sejarah tentang keberadaan penyakit atau sejarah ilmu kedokteran secara lengkap dari zaman ke zaman. Mereka menjelaskan bahwa manusia mencoba melakukan usaha mengobati penyakit sejak zaman purbakala atau disebut dengan istilah paleopathology atau paleomedicine, pada zaman itu penyakit dipelajari masih menggunakan tanda-tanda alam

\footnotetext{
${ }^{8}$ https://kbbi.web.id/sakit, diakses 6 Maret 2018.

${ }^{9} \mathrm{https}: / /$ www.merriam-webster.com/dictionary/illness, diakses 6 Maret 2018

${ }^{10}$ Irwan, Epidemiologi Penyakit Tidak Menular, (Yogyakarta: Deepublish, 2016), p.1

${ }^{11}$ Azwar Azrul. Pengantar Epidemiologi. (Jakarta : Binarupa Aksara, 1999), p.18
} 
seperti dari mumi atau jenazah manusia lainnya. Ritual-ritual penyembuhan masih sangat kental, juga masih banyak praktek sihir atau magic dan tradisi-tradisi purba. ${ }^{12}$

Lebih lanjut Magner dan Kim menjelaskan bahwa usaha manusia untuk bebas dari sakit mulai merambah kepada aspek komunitas, yaitu untuk membuat sejahtera warganya atau masyarakat seperti yang terjadi pada zaman Mesopotamia dan Mesir Kuno, hal itu tercatat di dalam hukum Hammurabi. Catatan tentang pengobatan terdapat dalam lembaran-lembaran papyrus. Lalu dijelaskan pula tradisi kesehatan atau medis yang berasal dari India dan China, dimana di India ada sebutan pengobatan ayurvedic, ilmu pengetahuan tentang pembedahan dan antomi tubuh. Di China ada pula pengobatan akupuntur dan konsep tentang moksa, pengetahuan tentang obat-obatan, konsep klasik Cina tentang anatomi. Lalu masuk ke zaman Yunani-Romawi dimana ada hubungan antara filosofi dengan pengobatan, dan masuk ke masa Hippocrates (Bapak Kedokteran), budaya Romawi sarat dengan keberadaan dewa-dewa penyembuh, tercatat juga peristiwa wabah penyakit seperti yang terjadi di daerah Siprus. Beranjak kepada Abad Pertengahan dimana terdapat masa keberadaan biara-biara dan mulai munculnya lembaga pendidikan universitas-universitas, pembedahanpun dilakukan di abad pertengahan ini, keberadaan perempuan dalam pengobatan mulai nampak, penyakit epidemic mulai diperhatikan termasuk wabah penyakit, berkembang pula pengobatan berbasis agama Islam seperti kasus dari Ibnu an-Nafis. ${ }^{13}$

Masuk ke zaman Renaissance dan revolusi sains, ilmu kedokteran menjadi lebih humanis, adanya otopsi, seni, anatomi, astrologi dan ilmu kimia. Keberadaan penyakit syphilis menjadi perhatian, ditemukannya sirkulasi darah, tranfusi darah. Setelah itu masuk ke budaya penemuan dunia baru seperti pengobatan ala komunitas Aztec, suku Maya, Inca di Benua Amerika. Di Amerika Serikat sebagai negara yang baru berdiri pada waktu itu mulai berkembang Dunia Kedokteran Lama, kedokteran di lingkungan para pahlawan atau pejuang kemerdekaan Amerika, seperti kematian George Washington yang sangat heroik, kedokteran praktis pada zaman terjadinya perang sipil, mulai adanya pendidikan kedokteran dan profesi kedokteran, spesialisasi kedokteran, mulai terbentuknya keberadaan rumah sakit, perawat dan sekolah perawat. Setelah itu

\footnotetext{
${ }^{12}$ Lois N Magner and Oliver J Kim, A History of Medicine, Third Edition, (New York: CRC Press, 2017), p.17-36

${ }^{13}$ Lou N Magner and Oliver J Kim, A History of Medicine, Third Edition, (New York: CRC Press, 2017), p.37-133
} 
berkembang pula pengobatan alternative, pengobatan komplementer dan integrasi, pengobatan berbasis agama dan iman kepercayaan seperti gerakan Healing Faith, Christian Science, ada pula diet modern. Mengenai teori kedokteran, perawatan kedokteran, dan pencegahan, ini merupakan ciri dari ilmu kedokteran/pengobatan pada abad ke-19 dan abad 20, di dalamnya mulai dibahas tentang nutrisi, vaksinasi, berkembangnya ilmu dan seni pembedahan, anestesi atau pembiusan, kebidanan, antiseptic, infeksi nosocomial, berkembang juga mikrobiologi kedokteran dengan tokoh utama Louis Pasteur dan Robert Koch, munculnya isu penyimpangan dengan munculnya senjata kimia, biologi dalam medan perang. ${ }^{14}$

Perkembangan berikutnya adalah berkembangnya ilmu diagnosa dan terapi, adanya serum terapi, imunologi, antibiotik, dan tentang isu kesalahan medis atau malpraktek, mulai diperhatikannya pemberian obat yang lebih aman dan efesien. Lalu berlanjut kepada masa kini yang lebih menekankan pada kemakmuran dan kemapanan, sehingga isu kesehatan publik atau kesehatan masyarakat dan kepedulian manusia pada lingkungan sekitarnya menjadi fokus perhatiannya. Isu lain seperti keluarga berencana, pengendalian angka kelahiran dan aborsi, juga mengenai polusi pada lingkungan hidup manusia menjadi pokok perhatian umat manusia. ${ }^{15}$

Sejarah manusia untuk memahami apa itu sakit, penyakit dan mengusahakan kesembuhan atau kesehatan adalah perjalanan yang sangat panjang dan sampai saat inipun usaha tersebut untuk terus dilakukan, agar manusia mampu menjaga kesehatan dan kesembuhan seperti yang diharapkan oleh semua orang.

Pada pertengahan tahun 2020, yaitu bulan Juni usaha umat manusia untuk melawan penyakit sedang diuji lagi, lewat menyebarnya wabah virus corona atau penyakit yang resmi disebut COVID-19, yang awal mulanya ditemukan di suatu kota di China yang bernama Wuhan, lalu menyebar ke kota-kota lain dan menyebar ke seluruh dunia, dan sampai saat ini (data per 17 Juni 2020) wabah virus corona sudah menyerang 213 negara dan teritori, secara global orang meninggal dunia sebanyak 451.429 orang, dan lebih dari 8.406.660 orang terinfeksi virus corona, sedangkan untuk Indonesia yang

\footnotetext{
${ }^{14}$ Loui N Magner and Oliver J Kim, A History of Medicine, Third Edition, (New York: CRC Press, 2017), p.154-187

${ }^{15}$ Magner \& Kim, 306-334.
} 
terserang Covid-19 adalah 41.431 orang, dengan orang yang meninggal sebanyak 2.276 orang. ${ }^{16}$

\section{Faktor-faktor yang Menyebabkan Terjadinya Sakit dan Penyakit}

Kondisi atau keadaan sakit seseorang pastilah disebabkan oleh banyak faktor. Faktor-faktor penyebab sakit seperti telah dibahas terdahulu pada awal mulanya atau pada zaman dahulu banyak bersifat spekulatif, adalah Hypocrates (460-377 SM), yang dikenal sebagai bapak kedokteran yang mengemukakan penyebab sakit adalah karena pengaruh lingkungan terutama air, udara, tanah dan cuaca. Perkembangan ilmu pengetahuan kedokteran terus mengalami perkembangan dengan ditemukannya mikroba dan parasite oleh Louis Pasteur (1822-1895), sehinga membawa kepada kemajuan dibidang mikrobiologi, dan ditemukannya kuman sebagai penyebab penyakit. Ilmu tentang penyebab sakit penyakit dan pola hidup manusia dalam menyikapi penyebab penyakit dan penyebarannya, juga bagaimana pencegahan terhadap penyakit dikenal dengan Epidemiologi.

Terdapat setidaknya enam teori mengenai penyebab terjadinya sakit dan penyakit yaitu: Pertama, Teori Contagion: Penyakit diakibatkan dari kontak antar manusia, berdasarkan pengamatan penyakit kusta di Mesir. Kedua, Teori Hippocrates: Penyakit diakibatkan dari pengaruh air, udara, tanah, cuaca dan faktor lingkungan lainnya, namun belum ada penjelasan posisi manusia dalam interaksi tersebut, dan faktor lingkungan yang seperti apa yang dapat menyimbulkan sakit. Ketiga, Teori Humoral: Penyakit diakibatkan oleh gangguan keseimbangan cairan di dalam tubuh, tubuh terdiri dari empat cairan, putih, kuning, merah dan hitam. Bila terjadi ketidak-seimbangan, maka akan timbul penyakit, jenis penyakit tergantung pada cairan yang dominan, berkembang dari Cina.

Sedangkan yang Keempat, Teori Miasma: Penyakit timbul akibat sisa makhluk hidup yang mengalami pembusukan sehingga menyebabkan pengotoran udara dan lingkungan sekitar. Kelima, Teori Jasad Renik: Penyakit diakibatkan oleh jasad renik atau

${ }^{16}$ Internet, diambil dari: https://www.worldometers.info/coronavirus, diakses tanggal 18 Juni 2020 
mikro organisma, berkembang setelah ditemukannya mikroskop. Keenam, Teori Ekologi Lingkungan: Interaksi manusia dengan lingkungan dapat menimbulkan penyakit.

Dalam Epidemiologi yaitu ilmu yang mempelajari pola kesehatan dan penyakit dikenal istilah segitiga epidemiologi atau Epidemiological Triad/ Triangle yang dikemukakan oleh Gordon dan La Richt (1950), model segitiga ini menggambarkan bahwa timbulnya penyakit pada manusia disebabkan oleh tiga faktor utama yaitu host, agent, dan environment, seperti yang dampak dalam dua gambar di bawah ini:

\section{Host}

\section{Environment}

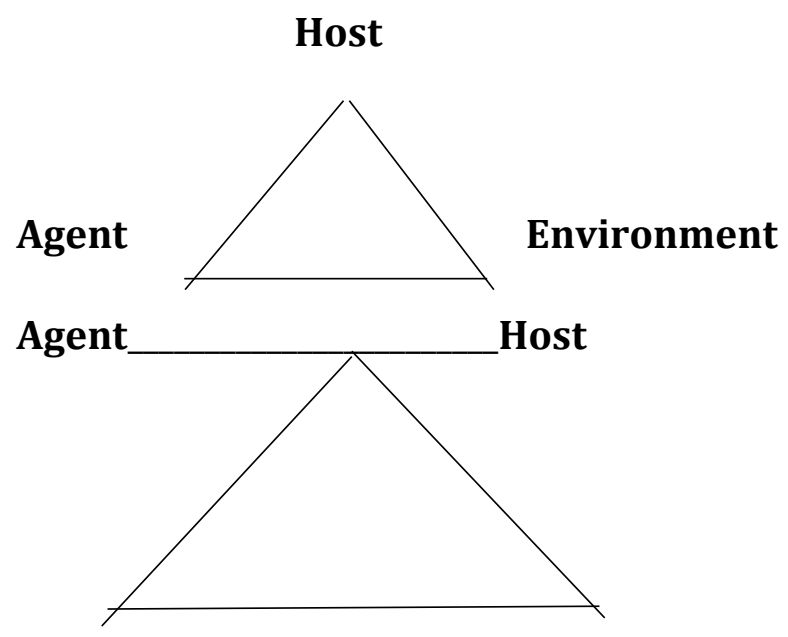

Dari dua gambar tersebut dapat dijelaskan pola terjadinya penyakit dan faktorfaktor dari terjadinya penyakit tersebut pada manusia sebagai berikut: ${ }^{17}$ Agent adalah suatu elemen makhluk hidup atau bukan makhluk hidup yang kehadirannya atau ketidak-hadirannya dapat menimbulkan atau mempengaruhi perjalanan suatu penyakit. Jenis agent adalah nutrient, kimia, biologi, fisik dan mekanik. Agent kimia adalah: pestisida, zat aditif, obat-obatan, zat yang diproduksi oleh tubuh, logam berat, minuman keras, bahan-bahan kosmetik. Agent Nutrisi adalah: Karbohidrat bila berlebihan bisa menimbulkan obesitas, lemak bila berlebihan dapat menimbulkan hyperlipidemia, protein bila kekurangan dapat menimbulkan malnutrisi, vitamin, mineral, dan air. Agen Mekanik adalah seperti friksi yang kronik misalnya pemakaian sepatu yang sempit bisa mengakibatkan verucca vulgaris atau kutil; kompresi atau daya mekanik menekan dan memutar. Agent Fisika adalah radiasi, suhu udara, kelembaban, intensitas suara, panas, terang cahaya. Agen biologis adalah pathogen, virus, inveksitis.

\footnotetext{
${ }^{17}$ Randy M Page, Galen E Cole, dan Thomas C Timmreck., Basic Epidemiological Methods and Biostatistics: A Practical Guidebook, (Massachusetts: Jones and Bartlett Publishers, 1995), p.16-29.
} 
Host adalah semua faktor yang ada pada diri manusia yang dapat menyebabkan timbulnya penyakit seperti: Faktor keturunan, umur, jenis kelamin, ras, status pernikahan, pekerjaan dan gaya hidup. Environment adalah gabungan dari seluruh kondisi dan pengaruh luar yang mempengaruhi kehidupan organisme seperti fisik, biologis, sosial ekonomi dan lain-lain.

Dari penjelasan-penjelasan di atas maka berikut ini adalah faktor-faktor yang menyebabkan terjadinya penyakit.

\section{a. Faktor Lingkungan}

Beberapa penyakit diakibatkan karena faktor lingkungan yang buruk seperti lingkungan yang kotor, sanitasi yang buruk, tidak tersedianya air bersih, tidak adanya MCK (mandi, cuci, kakus) dapat menyebabkan kuman penyakit tumbuh subur, dan dengan mudah terjadinya penyakit menular, contohnya: penyakit kolera, difteri, disentri, tuberculosis dan lain-lain.

\section{b. Faktor Biologis}

Faktor biologis adalah faktor yang berhubungan dengan kondisi tubuh jasmani seseorang misalnya gangguan pada organ-organ tubuh baik organ tubuh vital seperti jantung dan pembuluh darah, paru dan sistem pernafasan, ginjal, usus dan sistem pencernaan. Gangguan pada telinga, hidung, tenggorokan, sistem syaraf, kandungan dan kehamilan, penyakit pada anak-anak. Juga gangguan yang berhubungan dengan sistem metabolisme dan hormonal. Ada pula gangguan yang tidak vital seperti gatal-gatal, terkilir, tergores di tubuh dan lain-lain.

\section{c. Faktor Psikologis}

Faktor psikologis juga dapat menjadi penyebab manusia sakit, bahkan penyebab pasien ada di rumah sakit menurut Gerald Faith, seperti dikutip oleh Rumondang Panjaitan bahwa 75-85\% penyakit yang ada di rumah sakit disebabkan oleh masalah kejiwaan atau psikis seseorang. Contohnya seseorang yang sering terkena penyakit flu, demam dan pusing dalam waktu yang berdekatan bisa disebabkan berkurangnya daya tahan tubuh dikarenakan adanya 
kecemasan atau ketegangan jiwa. ${ }^{18}$ Mengenai sakit yang diakibatkan karena faktor psikologis atau kejiwaan sering mengakibatkan terjadinya krisis pada diri seseorang. Dokter Benard Fox dari Boston menemukan bahwa pria-pria yang mengalami masalah psikologi seperti depresi kemungkinan dua kali menderita kanker disbanding pria-pria yang tidak menderita depresi. ${ }^{19}$

Sakit pada manusia sangat berhubungan erat dengan kondisi krisis pada diri seseorang karena mengalami banyak masalah atau problema, memang krisiskrisis tersebut ada yang tingkatannya kecil, sedang, dan berat, dimana bila tingkatannya berupa krisis berat diperlukan perawatan intensif. Menurut Wiryasaputra, terdapat tiga kategori dari krisis:

1. Krisis perkembangan (developmental), krisis ini berkaitan dengan perkembangan manusia dari sejak lahir sampai meninggal. Misalnya: krisis saat kelahiran, masa bayi, kanak-kanak, remaja, pemuda, dewasa, pernikahan, usia setengah baya, usia matang, usia lanjut, dan meninggal.

2. Krisis situasional atau accidental, krisis ini berkaitan dengan kecelakaan atau yang berkenaan dengan kehilangan atau kedukaan. Misalnya: menderita sakit, kehilangan sesuatu atau seseorang seperti jabatan/kedudukan, harta benda, kesempatan, impian/cita-cita, keluarga (anak, pasangan, orang tua). Krisis ini bisa juga karena tidak lulus ujian, perceraian, pisah ranjang, kematian orang yang dikasihi khususnya saat masih di usia muda.

3. Krisis eksistensial, ini merupakan krisis yang disebabkan oleh konflik dan tekanan batin. Misalnya: harga diri yang dinjak-injak, kehilangan kesempatan untuk mengambil keputusan tentang hidupnya, tidak bisa memiliki kebebasan dan tanggung jawab, artinya nilai-nilai kemanusiaan secara universal hilang.

Wiryasaputra juga menambahkan, pada dasarnya krisis berhubungan dengan kehilangan, kedukaan, tidak lulus ujian, lamaran pekerjaan ditolak, lamaran pernikahan ditolak, perceraian, dihukum, dipenjara, putus pengharapan/asa, merasa sendiri, kesepian, depresi, keinginan bunuh diri, konflik

\footnotetext{
${ }^{18}$ Rumondang Panjaitan, Daniel Susanto (Editor), Sekilas Tentang Pelayanan Pastoral Di Indonesia..., 163.

${ }^{19}$ Bernie S. Siegel., Cinta, Pengobatan, dan Mukjizat. (Jakarta: PT Gramedia Pustaka Utama, 2003), p.86.
} 
batin, psychological fatige (kelelahan psikologi), penyalah-gunaan obat, pindah pekerjaan, ada anggota keluarga yang baru, konflik antar anggota keluarga, kehilangan anggota keluarga karena meninggal, pindah ke tempat yang jauh, diculik dll, kehamilan, kelahiran, perselingkuhan, menjadi duda, menjadi janda, sakit berkepanjangan, kelelahan dalam menjalani pekerjaan, kehabisan energi, dan lain sebagainya. ${ }^{20}$

\section{d. Faktor Spiritual}

Seseorang bisa sakit karena adanya masalah-masalah yang berhubungan dengan dosa. Terutama dosa yang dipendam, yang tersembunyi bahkan bertahun-tahun lamanya, misalnya dendam yang mengakibatkan pertikaian, perselisihan bahkan peperangan. ${ }^{21}$ Spiritual telah menjadi areal yang diabaikan dalam pendidikan dan penelitian di bidang kesehatan. Hal ini benar-benar terjadi sekalipun fakta menunjukkan bahwa kepercayaan seseorang mempengaruhi hasil perawatan, pencegahan penyakit, mencegah penyebaran penyakit, pemulihan dan bagaimana pasien memandang masalah kesehatan. ${ }^{22}$ Di antara berbagai faktor yang disebutkan, maka faktor spiritual lah yang paling penting, dan akan dibahas lebih lengkap dalam penjelasan lebih lanjut.

\section{e. Faktor Sosial, Ekonomi, Budaya, Pendidikan dan Politik}

Beberapa penyakit dapat diakibatkan karena faktor sosial budaya di suatu daerah, misalnya di budaya orang pedesaan jawa ketika anak-anak mereka masih berusia balita dan mengalami sakit mereka memiliki kepercayaan anaknya akan menjadi pintar, lalu orang tua membiarkan anaknya tidak dirawat di rumah sakit, sehingga seringkali menimbulkan sakit yang lebih parah. Juga terdapat praktekpraktek budaya di daerah tertentu yang bisa menyebabkan seseorang menderita sakit.

\footnotetext{
${ }^{20}$ Totok S. Wiryasaputra \& Rini Handayani, Pengantar Kedalam Konseling Pastoral, (Salatiga: Asosiasi Konselor Pastoral Indonesia, 2013), 83-84.

${ }^{21}$ Bandingkan dengan pendapat Erhard Schneider, Maukah Engkau Sembuh?. Batu: YPPII: Departemen Literatur, 1992), dan dr. Daniel E Fountain, Kesehatan, Alkitab \& Gereja. (Bandung: Lembaga Literatur Baptis, 2003), 10-20.

${ }^{22}$ J. Lebron McBride, Gary Arthur, Robin Brooks, Pilkington Lloyd., The Relationship Between a Patient's Spirituality and Health Experiences. Family Medicine 1998 February; 30(2): 122-126
} 
Rendahnya pendidikan dan ekonomi juga menjadi faktor seringkali terjadi banyak penyakit parah, apalagi tempat pelayanan kesehatan jauh dari jangkauan mereka. Ditambah pula situasi sosial politik di suatu negara, apabila situasi sosial politik di suatu negara kurang kondusif bahkan terjadi konflik sektarian dan menyebabkan terjadinya peperangan dan konflik berkepanjangan, maka akan banyak terjadi penderitaan yang dialami rakyat negara tersebut, jumlah penderita sakit akan sangat membludak mengingat berkurangnya tenaga medis dan hancurnya sarana-sarana kesehatan karena terkena dampak peperangan. ${ }^{23}$

\section{f. Faktor Perilaku atau Gaya Hidup Seseorang}

Perilaku atau gaya hidup seseorang bisa mengakibatkan seseorang menderita sakit. Misalnya gaya hidup di perkotaan dimana orang-orang menjadi jarang melakukan aktifitas olah raga, gaya hidup mereka mulai dari rumah ke tempat pekerjaan dan pulang lagi ke rumah telah dibantu dengan teknologi transportasi dan teknologi internet. Tubuh mereka kurang gerak alias kelebihan kalori/energi, namun pola makan mereka tidak sehat, banyak mengkonsumsi makanan berlemak, sehingga mengakibatkannya penumpukan lemak yang berlebih di dalam tubuh mereka.

Berlebihnya lemak dalam tubuh seseorang dapat mengakibatkan terjadi berbagai penyakit seperti tekanan darah tinggi, penyakit jantung dan pembuluh darah, penyakit diabetes mellitus atau gula, terkena serangan stroke, dan mungkin saja dapat mengakibatkan kematian.

Gaya hidup yang tidak baik seperti kebiasaan merokok, minum minuman keras, bahkan kecanduan melakukan sesuatu atau mengkonsumsi sesuatu dapat mnengakibatkan seseorang menderita sakit. Misalnya kecanduan merokok,

\footnotetext{
${ }^{23}$ Bandingan berdasarkan laporan dari majelis umum PBB (Persatuan Bangsa-bangsa) mengenai sasaran pembangunan berkelanjutan atau SDGs (Suistanable Developments Goals), yang mana ditentukan 17 tujuan universal, 169 target, dan 230 indikator, penelitian berdasarkan data dari tahun 1990-2015, bahkan bisa memprediksi ke tahun 2030, Published Online September 21, 2016 http://dx.doi.org/10.1016/S01406736(16)31467-2; Measuring the health-related Sustainable Development Goals in 188 countries: a baseline analysis from the Global Burden of Disease Study 2015
} 
alkohol, seks atau pornografi, internet, game online, berbelanja, bekerja dan bentuk kecanduan yang lainnya dapat mengakibatkan seseorang menderita sakit.

Faktor kelalaian manusia termasuk juga sebagai penyebab terjadinya sakit, misalnya kelalaian mnusia ketika menjalankan alat-alat tranportasi baik di darat, laut dan udara. Di darat sendiri seperti di jalan raya atau lalu lintas akibat kelalaian manusia sering mengakibatkan kecelakaan lalu lintas. Akibat dari kecelakaan lalu lintas ini banyak menimbulkan berbagai kerugian seperti timbulnya sakit penyakit, terjadinya kecacatan pada tubuh, bahkan bisa mengakibatkan kematian, angka kematian akibat kecelakaan ini sangat besar.

\section{g. Faktor Bencana Alam}

Faktor berikut ini tidak bisa kita hindari, yaitu faktor bencana-bencana alam, seperti: bencana tsunami, topan badai, gempa bumi, banjir, longsor, gunung meletus. Namun berkat kemajuan ilmu pengetahuan beberapa bencana bisa diantisipasi atau dimitigasi untuk menghindari terjadinya banyak korban jiwa. Bencana alam dapat terjadi juga karena faktor kesalahan manusia, seperti bencana banjir yang diakibatkan eksploitasi hutan oleh manusia sehingga hutan menjadi gundul, rusak hal tersebut berdampak pada terjadinya bencana. Namun saat ini mulai meningkatnya kesadaran manusia untuk menjaganya kelestarian alam agar dapat mengurangi dampak bencana alam.

\section{Berkembangnya Penyakit Tidak Menular Pada Masa Kini}

Setelah membahas berbagai faktor penyebab timbulnya penyakit, maka perlu dibahas berkembangnya penyakit tidak menular pada situasi saat ini. Pengertian penyakit sebenarnya adalah adanya gangguan pada fungsi organ manusia yang diakibatkan oleh berbagai faktor baik internal maupun eksternal, sehingga manusia tersebut merasakan penderitaan dan menyebabkan terjadi penurunan kinerja dan kesejahteraan. ${ }^{24}$

Kondisi dan situasi saat ini sangat berbeda dengan kondisi pada masa lampau, banyak terjadi perubahan yang begitu cepat, mengingat kemajuan pesat pada bidang

\footnotetext{
${ }^{24}$ Irwan, Epidemiologi Penyakit Tidak Menular, (Yogyakarta: Deepublish Publisher, 2016), p.1
} 
teknologi informasi dan komunikasi, berkembangnya internet, online, media sosial sebagai alat komunikasi telah membentuk hubungan antar manusia di dunia terasa sangat mudah. Hubungan antar negara menjadi tanpa batas melalui dunia maya, manusia tidak perlu lagi mengalami kesulitan dalam aktifitasnya seperti berkendaraan, berbelanja, bekerja, belajar dan sebagainya karena semua aktifitas tersebut bisa dilakukan hanya melalui genggaman tangan lewat alat komunikasi seperti HP (handphone) dan laptop.

Namun adanya berbagai kemudahan ini tentunya bisa menimbulkan dampak negatif seperti munculnya penyakit pada manusia akibat berkurangnya aktifitas atau gerak pada pola hidup manusia saat ini. Maka timbullah banyaknya masalah dan penyakit. Pada masa lampau penyakit yang timbul banyak disebabkan karena faktor infeksi dan penyakit tersebut menular. Tapi pada saat ini justru mengalami perubahan pola penyakit, karena yang terjadi adalah penyakit non infeksi dan penyakit yang tidak menular.

Penyakit tidak menular tersebut adalah seperti penyakit jantung, karsinoma (sel kanker), hipertensi dll. Juga penyakit pada saat ini lebih mengarah kepada faktor-faktor seperti fertilitas, menopause, kecelakaan, kenakalan remaja, penyalah-gunaan obat-obat terarang, merokok, masalah keluarga berencana, masalah kesehatan lingkungan, masalah pengadaan tenaga kesehatan, sarana kesehatan dan sebagainya. ${ }^{25}$

Penyakit tidak menular seperti kardiovaskuler, stroke, diabetes mellitus, penyakit paru obstruktif dan kanker tertentu digolongkan sebagai kelompok utama dari penyakit tidak menular yang memiliki faktor resiko yang sama. Faktor resiko tersebut antara lain konsumsi rokok, pola makan yang tidak seimbang, makanan yang mengandung zat adiktif, kurang melakukan olah raga, dan adanya kondisi lingkungan yang kurang mendukung kesehatan. Gaya hidup dan kondisi sosial ekonomi, sangat berpengaruh kepada timbulnya penyakit tidak menular ini. Berdasarkan survey kesehatan rumah tangga, proporsi kematian akibat penyakit tidak menular meningkat dari 25,41\% di tahun 1980 menjadi 48,53\% di tahun 2001, secara global pun data dari WHO (Organisasi

${ }^{25}$ Irwan, p. 2 
Kesehatan Dunia) memperkirakan penyakit tidak menular telah menyebabkan $60 \%$ kematian dan $43 \%$ kesakitan. $^{26}$

\section{Pelayanan Pastoral Terhadap Orang Sakit}

Seperti dikatakan di atas, pelayanan pastoral terhadap orang sakit merupakan salah satu dari berbagai pelayanan pastoral, namun bukan berarti pelayanan pastoral terhadap orang sakit hanyalah suatu pelayanan yang sederhana. Karena pelayanan pastoral terhadap orang sakit ini sebenarnya adalah suatu pelayanan yang luas dan kompleks. Hal tersebut dikarenakan membahas tentang orang sakit sangat luas cakupannya, baik dari segi orangnya, mulai dari anak-anak sampai dengan lansia, dari segi tempatnya bisa di luar rumah sakit dan bisa di dalam rumah sakit, belum pula dari segi penyakitnya bisa dikategorikan penyakit menular atau tidak menular, penyakit ringan, menengah, atau penyakit berat berat dan bahkan penyakit yang bisa menimbulkan kematian atau terminal illness. Juga dari segi para tenaga kesehatannya mulai dari dokter, perawat, dan paramedis-paramedis lainnya.

Saat inipun terdapat banyak jenis pelayanan pastoral terhadap orang sakit, misalnya pelayanan pastoral khusus untuk pasien kanker, pasien paliatif, pasien terminal illness, pasien anak-anak, pasien lansia, dan lain-lain. ${ }^{27}$ Tentunya pelayanan pastoral untuk orang sakit perlu disesuaikan dengan peruntukkannya. Tetapi pada penelitian ini akan difokuskan pada pelayanan di Rumah Sakit khususnya pasien yang berada di ruang rawat inap.

Pelayanan pastoral yang tadinya hanya digunakan di ruang lingkup gereja telah mengalami perkembangan bukan hanya untuk kepentingan di dalam gereja namun sekarang meluas dengan adanya pelayanan pastoral terhadap orang sakit. Pelayanan pastoral terhadap orang sakit di Indonesia pada awalnya mulai berkembang sejak dekade tahun 1970-an, dengan didirikannya fakultas theologia program studi pastoral diberbagai universitas yang dirintis melalui program Diploma Tiga. Tetapi pelayanan pastoral sering mengalami kesalahan persepsi bahwa hanya pelayanan kebaktian singkat

\footnotetext{
${ }^{26}$ Irwan, p.3

27 Totok S Wiryasaputra, Pendampingan Pasien Kanker, (Jakarta: PELKESI, 2007), p.4-5.
} 
di rumah orang sakit atau di rumah sakit, padahal pelayanan pastoral tidaklah sesempit hanya menghadirkan kebaktian singkat di rumah sakit, atau bukan hanya seperti itu. ${ }^{28}$

Adapun menurut Daniel Susanto alasan utama untuk mendampingi orang sakit adalah meneladani dari Tuhan Yesus sendiri, alasan kedua adalah bahwa setiap orang Kristen atau gereja terpanggil untuk melakukan caring community atau kepedulian terhadap komunitas atau sesama. Biasanya orang-orang yang sakit senang kalau dikunjungi karena merasa diperhatikan dan dikasihi, dan mereka yang sedang sakit membutuhkan kawan yang dapat mendengar, dan mendampingi di dalam pergumulannya. ${ }^{29}$

Tujuan dari pelayanan pastoral terhadap orang sakit adalah memberi pertolongan dan pendampingan, Daniel Susanto mengutip pendapat Roscam Abbing yang menyatakan bahwa pada intinya ada tiga tujuan dalam pelayanan pastoral terhadap orang sakit, yaitu: Pertama, agar orang sakit tersebut tetap tekun dalam imannya; kedua, agar iman orang sakit tersebut dapat diperdalam; dan ketiga, agar iman orang sakit tersebut dapat menghasilkan buah-buah Roh walau situasinya dalam kesulitan dengan penyakit yang diidapnya. ${ }^{30}$

\section{Fungsi Pelayanan Pastoral Terhadap Orang Sakit}

Menurut Yakkum yaitu Yayasan Kristen Untuk Kesehatan Umum yang memiliki belasan rumah-rumah sakit di Indonesia, dalam buku yang merupakan suatu suatu modul pelayanan pastoral dijelaskan fungsi pelayanan pastoral terhadap orang sakit sebenarnya meliputi dua hal yaitu pendampingan pastoral (care giving) dan pelayanan yang lebih khusus yaitu konseling. Di dalamnya dibutuhkan kesungguhan dari para pelayan pastoral atau konselor untuk melibatkan semua yang ada di dalam tubuh para pelayan pastoral tersebut, seperti telinga untuk mendengar, mata untuk melihat, namun

${ }^{28}$ Daniel Susanto, Perspektif Kristen Pelayanan Pastoral Untuk Orang Sakit, in Mendampingi dengan Hati, Edited by YAKKUM (Yayasan Kristen Untuk Kesehatan Umum) (Surakarta: Yakkum Press, 2008), p.2.

${ }^{29}$ Daniel Susanto, Perspektif Kristen Pelayanan Pastoral Untuk Orang Sakit ..., p.3

${ }^{30}$ Ibid., p. xi-xv, 3. 
yang terpenting menggunakan telinga dan mata batin kita untuk melayani dengan sepenuh hati kita. ${ }^{31}$

Di bawah ini, penulis menyatakan lima fungsi pelayanan kesembuhan secara umum seperti yang dikemukakan oleh Yakkum, mengutip dari pendapat dari William A Clebsch dan Charles R Jaekle. ${ }^{32}$ Namun mengingat lima fungsi tersebut belum menyentuh fungsi utama yaitu Amanat Agung, maka penulis menambahkan fungsi ke enam yaitu fungsi untuk melaksanakan Amanat Agung Yesus Kristus. Sebenarnya satu fungsi tersebut adalah fungsi yang sangat penting yang tidak boleh dilupakan, yang tidak tercatat di dalam buku tersebut, yaitu pelayanan pastoral adalah alat untuk melaksanakan Amanat Agung Yesus Kristus. 33

Beberapa pakar pastoral konseling turut mendukung juga bahwa pelayanan pastoral terhadap orang sakit adalah sebagai alat pelaksanaan Amanat Agung mereka adalah sebagai berikut: Julianto Simanjuntak, Yakub Susabda dan lainnya untuk di Indonesia, sedangkan di luar negeri seperti di Amerika terdapat Jay Adam, John MacArthur Jr., dan lain-lain.

Berikut ini adalah enam fungsi pelayanan pastoral terhadap orang sakit tersebut.

\section{Fungsi Menyembuhkan atau Healing}

Fungsi penyembuhan dalam pelayanan pastoral tidak hanya menyembuhkan secara fisik-biologis semata, melainkan menyentuh aspek mental, emosional, dan spiritual. Pada dasarnya pelayan pastoral tidak dapat menyembuhkan penyakit seseorang, namun pelayanan kesembuhan ini adalah ikut sertanya dan kepedulian akan hadirnya proses penyembuhan yang datang dari Allah sendiri.

Kesembuhan yang diharapkan tentunya kesembuhan yang seluas-luasnya yaitu yang menyentuh semua aspek kehidupan manusia, baik tubuhnya, jiwanya dan rohnya. Juga relasinya dengan Tuhan dan sesama, relasinya dengan

\footnotetext{
${ }^{31}$ Yayasan Kristen untuk Kesehatan Umum (Ed.), Mendampingi Dengan Hati: Modul Pendampingan Pastoral....., p.X

${ }^{32}$ Ibid., p.xi-xvii

${ }^{33}$ Julianto Simanjuntak (Ed.), Konseling dan Amanat Agung, (Tangerang: Yayasan Pelikan/Peduli Konseling Nusantara, 2010), p.16-17.
} 
lingkungan dan sekitarnyapun menjadi perhatian dalam pelayanan kesembuhan ini.

\section{Fungsi Menyokong atau Mendukung (Sustaining)}

Ketika seorang sakit, apalagi penyakit terminal yaitu penyakit yang membawa kepada kematian, mereka mengalami putus pengharapan maka para pelayan pastoral perlu melakukan dukungan. Saat mereka mengalami penderitaan yang sangat dalam seperti bingung, putus asa, shock, berontak dan sebagainya, kadang keberadaan pelayan cukup hadir atau ada disamping mereka tanpa harus mengeluarkan banyak perkataan apalagi nasihat. Bentuk dukungan, sokongan, topangan adalah pemberian semangat atau penguatan kembali kepada orang yang digembalakan.

\section{Fungsi Membimbing atau Guiding}

Fungsi pembimbingan ini adalah untuk membantu pasien dan keluarganya dalam pengambilan keputusan, misalnya ketika ada kasus amputasi kaki/tangan, pasien perokok berat harus menghentikan kebiasaan merokoknya, atau ketika ada pasien yang harus memilih alat kontrasepsi (KB) dan lain-lain. Pada dasarnya pengambil keputusan adalah pasien, pelayan pastoral adalah pendamping, pembimbingan diperlukan karena seringkali pengambilan keputusan sangat berhubungan dengan masalah etika.

\section{Fungsi Memperbaiki Hubungan atau Reconciling}

Tiga fungsi di awal lebih berfokus pada diri orang yang ditolong, namun fungsi keempat ini adalah untuk memperbaiki hubungan orang yang ditolong tersebut dengan orang lain bisa orang tuanya, pasangannya, temannya, kekasihnya, atasannya, bahkan bisa juga dengan Tuhannya.

Fungsi ini dilaksanakan apabila terjadi konflik atau ketegangan dengan pihak lain, pelayan pastoral akan berfungsi sebagai mediator, penengah di antara pihak-pihak yang bersitegang/berkonflik. Hal ini telah diteladani oleh Tuhan Yesus yang telah menjadi Mediator buat umat manusia.

\section{Fungsi Mengasuh/Mendidik atau Nurturing.}


Fungsi ini adalah penambahan atau lanjutan dari fungsi membimbing, dimana diharapkan orang yang ditolong dapat mengerti informasi-informasi terbaru tentang kehidupan yang lebih baik, dan dapat mengembangkan potensi yang ada untuk dapat memperoleh kedewasaan dengan kasih dan disiplin. Seperti Allah memberi penghargaan kepada setiap orang, demikian juga para pelayan pastoral, hendaknya dengan kasih memberikan pengasuhan/pendidikan tentang segala seluk beluk tentang penyakit yang diderita pasien dengan sejelas-jelasnya.

Begitu pula yang diharapkan dalam lingkup yang lebih luas, masyarakat dapat mendukung kualitas kesehatan untuk hidup mereka sendiri, maka fungsi ini sangat berkaitan erat dengan tindakan preventif dan promotif dari rumah sakit atau unit pelayanan kesehatan.

\section{Fungsi Penggenapan Amanat Agung}

Menyikapi pelayanan pastoral terhadap orang sakit yang selama ini ada, Julianto Simanjutak dalam bukunya yang berjudul "Konseling dan Amanat Agung," mengingatkan gereja-gereja di Indonesia untuk peduli terhadap pelayanan pastoral mengingat data bahwa banyaknya penderita sakit depresi, kecemasan, dan gangguan jiwa lainnya. Beliau mengutip data dari WHO bahwa di seluruh dunia setiap satu tahun terjadi satu juta bunuh diri, setengah dari angka tersebut dikarenakan gangguan jiwa. Di Indonesia sendiri terdapat 26 juta jiwa yang mengidap gangguan jiwa, separuhnya mengalami depresi. Adapun kerugian negara akibat gangguan jiwa pada tahun 1997 adalah 31 Trilyun rupiah per tahun, angka bunuh diri di Indonesia adalah 1800 orang per 100.000 penduduk. $^{34}$

Dasar dari keperluan gereja untuk peduli terhadap pelayanan terhadap orang sakit, khusunya konseling terhadap para pasien adalah Amanat Agung Tuhan Yesus, motivasi yang salah akan mengakibatnya esensi dari pelayanan pastoral terhadap orang sakit akan hilang. Peran Roh Kudus dan Firman Allah tidak boleh diabaikan, justru peranNya harus lebih digalakkan lagi, seperti yang dinyatakan oleh Julianto Simanjuntak mengutip perkataan dari Granger E Westberg bahwa setiap orang diberi mandat untuk merawat dan bertanggungjawab bagi dirinya, orang lain dan dunia (Kejadian 1:28), manusia adalah

\footnotetext{
${ }^{34}$ Julianto Simanjuntak (Ed.), Konseling dan Amanat Agung..., p.16-17.
} 
reprentatif Allah dalam merawat ciptaan. Semua penyembuhan tak terpisahkan dan tergantung pada Salib dan Kuasa Kebangkitan Kristus. Setiap orang percaya diharapkan menjadi agen penyembuhan. ${ }^{35}$

\section{Persyaratan Seorang Pelayanan Pastoral Terhadap Orang Sakit}

Pelayanan/pendampingan pastoral terhadap orang sakit pada dasarnya dapat dilakukan oleh setiap orang, namun karena dirasa penting beberapa rumah sakit Kristen telah menyediakan Pendeta, atau hamba-hamba Tuhan, atau petugas Pastoral untuk melakukan tugas pelayanan ini.

Tetapi baik tenaga pastoral khusus, maupun tenaga-tenaga sukarela lainnya tetaplah terdapat berbagai persyaratan yang harus dimiliki oleh para pelayan pastoral terhadap orang sakit. Mengenai persayaratan ini banyak pakar yang telah merumuskannya, diantaranya diungkapkan oleh Julianto Simanjuntak bahwa ada tiga macam syarat untuk menjadi seorang pelayan pastoral atau konselor yaitu: Pertama, Competence yaitu melakukan tugas dengan sebaik-baiknya; kedua, Integrity yaitu memiliki kejujuran, adil, menghormati orang lain, mengerti nilai-nilai kehidupan dan memahami keterbatasan-keterbatasan pribadinya; ketiga, Profesional And Scientific Responsibility artinya harus memiliki tanggung-jawab secara profesional dan tidak melakukan pelayanan dengan sembarangan. ${ }^{36}$

Mengenai kualitas atau persyaratan seorang pelayan pastoral, seperti dikutip oleh E.P. Gintings, bahwa Albert Ellis pernah menyatakan sepuluh kualitas personal yang harus dimiliki seorang pelayan pastoral atau konselor agar pelayanannya berjalan dengan efektif yaitu: Keaslian atau genuine, kejujuran, kedewasaan, kekuatan emosional, kehangatan, kesabaran, kepekaan, profesionalitas, rasa humor, keluwesan, dan berdaya tarik. ${ }^{37}$

Lawrence Brammer seorang guru besar dan praktisi konseling di Amerika dalam bukunya The Helping Relationship, seperti dikutip oleh Totok S. Wiryasaputra

\footnotetext{
35 Julianto Simanjuntak (Ed.),p.53.

${ }^{36}$ Julianto Simanjutak (Ed.), Perlengkapan Seorang Konselor, (Tangerang: Yayasan Pelikan Indonesia, 2014), p. 453

${ }^{37}$ E.P. Gintings, Konseling Pastoral: Terhadap Masalah Umum Kehidupan, (Bandung: Jurnal Info Media, 2009), p.88-91
} 
menyatakan beberapa karakter dasar yang harus dimiliki oleh para pelayan pastoral atau konselor sehingga efektif, yaitu: mengenal diri sendiri dan nilai-nilai yang dimilikinya, mengenal budaya orang yang didampingi, mengenal perasaan sendiri, menjadi teladan, berbelas kasih, bermoral dan beretika, serta bertanggung-jawab. ${ }^{38}$

Sedangkan menurut pendapat Totok S. Wiryasaputra sebagai pendiri AKPI (Asosisasi Konselor Pastoral Indonesia), dalam melakukan pelayanan untuk menolong sesama manusia, diperlukan sepuluh karakter dasar dan sepuluh ketrampilan dasar yang mesti dimiliki oleh seorang pelayan pastoral atau konselor. Untuk sepuluh karakter dasar adalah sebagai berikut: Empati (merupakan karakter yang paling utama yang dibutuhkan), tertarik untuk melakukan pelayanan pastoral, percaya pada proses, terbuka, spontan, tulus hati atau otentik, kenal diri, holistik, universalistik, dan otonom. ${ }^{39}$

Sedangkan sepuluh ketrampilan dasar yang mesti dimiliki adalah sebagai berikut: mendengarkan, memperjelas, memantulkan, menafsirkan, mengarahkan, meringkas, memusatkan, memberi informasi, mengajukan pertanyaan, dan menantang. ${ }^{40}$

Pada dasarnya pendapat para pakar mengenai persyaratan yang harus dimiliki oleh setiap pelayan pastoral dalam melayani orang sakit, bermuara pada tiga hal utama, yaitu pertama hal yang berkaitan dengan kemampuan, ketrampilan dan kompetensi; yang kedua adalah hal yang berkaitan dengan integritas atau karakter; dan yang ketiga berkaitan dengan pertumbuhan pribadi dan rohani dari para pelayan pastoral tersebut. ${ }^{41}$

\section{Persyaratan Pengetahuan}

Mengenai persyaratan pengetahuan para pelayan pastoral hendaknya memiliki yang pertama-tama pengetahuan tentang percakapan pastoral, percakapan pastoral menjadi syarat utama karena pasti dipergunakan saat melayani orang sakit. Percakapan pastoral adalah bagian dari pengetahuan tentang pengembalaan. Selain itu para pelayan pastoral harus memiliki pengetahuan tentang Firman Tuhan dan teologi pastoral. Dikarenakan melakukan pelayanan terhadap orang sakit, maka pelu mempunyai pengetahuan tentang

${ }^{38}$ Totok S. Wiryasaputra, Ready to Care: Pendampingan dan Konseling Psikologi, (Yogyakarta: Galangpress, 2006), p.100

${ }^{39}$ Ibid., p. 99-120

${ }^{40}$ Ibid., p. 124

${ }^{41}$ Daniel Susanto, Perspektif Kristen Pelayanan Pastoral Untuk Orang Sakit ..., p.13 
orang sakit dan masalah-masalah yang dihadapi orang sakit. Juga sebaiknya para pelayan mendapat pengetahuan yang baik tentang psikologi pastoral.

Dibawah ini untuk mendukung persyaratan pengetahuan dalam melayani orang sakit, akan dijelaskan mengenai apa yang dimaksud percakapan pastoral dan beberapa hal yang berhubungan dengan kondisi dan perilaku orang sakit.

\section{a. Percakapan Pastoral}

Pelayanan pastoral biasanya dimulai dengan melakukan kunjungan ke pasien, lalu dalam kunjungan tersebut diisi dengan percakapan pastoral, pokokpokok dalam percakapan tersebut diharapkan sesuai dengan tepat terhadap situasi dan kondisi dari pasien. Diharapkan dalam percakapan tersebut pasien dapat tetap hidup dengan Tuhan, mampu melihat, mengalami, dan merefleksikan tentang penderitaan sakitnya dari "kacamata" atau sudut pandang iman Kristen.

Diharapkan pasien dapat memahami dan menyelesaikan persoalannya seturut Firman Tuhan, untuk mencapai sasaran tersebut maka percakapan pastoral perlu mengikuti tahapan-tahapan. Adapun terdapat tiga tahapan dalam percakapan pastoral, yaitu tahapan permulaan, tahapan perkembangan percakapan dan tahapan akhir percakapan.

Tahapan permulaan biasanya percakapan yang bersifat umum tujuannya adalah untuk berkenalan, menciptakan rapport (hubungan yang baik), dan lebih mengenal kehidupan orang yang dilayani. Tahapan ini pelayan pastoral lebih banyak mendengar, menerima, namun perlu dijaga agar tidak terlalu lama pada tahapan ini agar waktu percakapan tidak dihabiskan pada tahapan awal ini.

Tahapan perkembangan percakapan adalah percakapan yang lebih mendalam, harapannya orang sakit tersebut dapat mengerti dan memahami akan sikap dan perasaannya dan masalah-masalah yang sedang dia hadapi. Pelayan pastoral tetap perlu mendengar, jangan menanggapi, mmeberi komentar bahkan langsung menyalahkan orang yang dilayani atau counter transferring. Apabila ada masalah yang pelik seperti pertengkaran suami dan istri yang bisa mengarah pada perceraian, maka perlu diarahkan kepada penanganan selanjutnya yaitu konseling pastoral hal ini dilakukan agar ada tindak lanjut yang lebih dalam. 
Tahapan akhir percakapan adalah tahapan dimana diharapkan setelah dia mengerti dan memahami tentang dirinya dan masalahnya, dia bisa mengatasi masalah tersebut dengan berdasarkan pada Firman Allah, setelah hal itu tercapai jangan melakukan khotbah pendek atau nasihat-nasihat yang berupa monolog pendek, namun apabila memungkinkan bisa dibacakan Alkitab dan ditutup dengan doa. Diharapkan pada tahapan akhir ini orang yang kita layani bisa terhibur, dikuatkan imannya, bertobat atau bertekad untuk hidup baru dalam Tuhan (tetapi semuanya tergantung pada masalah yang dihadapinya)..$^{42}$

\section{b. Mengetahui Fase-fase Perilaku Orang Sakit}

Para pelayan pastoral perlu mengetahui perilaku orang sakit, menurut Suchman, yang dikutip oleh Daniel Susanto, terdapat lima fase perilaku orang sakit, walaupun tentunya fase-fase ini bukanlah sesuatu yang mutlak. Kelima fase tersebut adalah: ${ }^{43}$

- Fase dirasakannya gejala: orang mulai merasakan adanya sesuatu yang mengganggu, ada tiga aspek dari yang dirasakannya. Aspek jasmani ada rasa sakit, tidak enak dan lemah; aspek pengenalan/interpretasi terhadap gejala tersebut; aspek emosional berupa kecemasan dan ketakutan. Terdapat dua hal yang dapat merugikan orang sakit yaitu mengingkari adanya sakit dan terlambat mencari pertolongan.

- Fase Diterimanya Rasa Sakit: orang mulai menyadari dan menerima sakit tersebut dan menyadari untuk membutuhkan pertolongan. Ia mulai mencari cara meringankan sakitnya dengan mencari informasi, nasihat dari orang lain dan sebagainya.

- Fase Mencari Pertolongan Pengobatan: Pada fase ini orang sakit mulai mencari pertolongan pada dokter, klinik, rumah sakit. Semakin serius penyakitnya semakin cepat ia mencari pertolongan, namun disisi lain bila dirasakan ringan gejala sakitnya bisa saja ia mencari pengobatan lain atau alternatif.

\footnotetext{
${ }^{42}$ Daniel Susanto, Perspektif Kristen Pelayanan Pastoral Untuk Orang Sakit ..., p. 8-11

${ }^{43}$ Ibid, p.4-5
} 
- Fase Menerima Dirinya Sebagai Pasien: Pada fase ini, seseorang yang telah mengunjungi dokter dan dirawat di rumah sakit menerima dirinya sebagai pasien, sebagai pasien ia begantung kepada orang lain seperti dokter dan perawat, ia tidak lagi bebas karena terikat pada peraturan-peraturan pengobatan bagi dirinya.

- Fase Penyembuhan: Fase ini adalah fase dimana prosedur pengobatan berakhir, pasien telah melepaskan perannya sebagai pasien, dengan berhentinya pengobatan berarti ada kemungkinan ia kembali kepada perannya semula, namun bisa juga bila ia mengalami pemulihan jangka panjang seperti cacat kronis maka peran sebagai pasien rehabilitasi jangka panjang masih disandangnya. Fase penyembuhan ini mengakibatkan adanya mantan pasien yang artinya ia harus hidup sebagai manusia yang sehat.

\section{c. Memahami Mengenai Kecemasan/Ketakutan yang Dialami Orang Sakit}

Orang sakit pada umumnya akan mengalami masalah psikis yang kurang menguntungkan, ia akan merasa tidak berdaya, pasif dan sangat bergantung pada orang lain seperti kepada pasangannya, dokter, perawat kepada rumah sakit dan sebagainya. Mereka menjadi kurang nyaman, tidak bisa bebas karena ketergantungan pada pihak lain, seringkali persaan tertekan, malu, marah, berontak, menyesali dirinya sendiri dan sebagainya. ${ }^{44}$

Garry R Collins menjelaskan pendapat dari James J Strain dan Stanley Grossman mengenai stress pada orang sakit baik secara psikis dan emosinya. Stress psikis pada pasien yang dirawat di rumah sakit mengalami tujuh macam stress, yaitu sebagai berikut:

- Ancaman Terhadap Integritas Diri: Pasien merasa tidak berdaya, tidak bisa melakukan aktifitas sesuai harapnnya, ia harus mengikuti aturan di rumah sakit, kondisi ini tentunya bisa mengancam diri orang tersebut. 
- Takut Terhadap Orang Asing Atau Orang Yang Belum Dikenal: Pada saat ia ditangani oleh orang lain yang belum dikenalnya, seringkali hal tersebut membuatnya takut.

- Kecemasan Untuk Berpisah: Selama menjalani perawatan di Rumah Sakit menyebabkan ia harus berpisah dari keluarga dan teman-temannya, hal ini bisa menimbulkan kecemasan.

- Takut Kehilangan Kasih dan Penghargaan: Penyakit dan luka dapat mengakibatkan kecacatan pada seseorang, dan dapat menyebabkan ketergantungan pada seseorang pula, hal ini dapat mengancam harga dirinya dan ia menjadi takut apabila melalui perubahan yang terjadi orang lain tidak mengasihi dan menghargainya.

- Takut Kehilangan Kontrol: Disebabkan beberapa fungsi tubuh orang sakit tidak dapat lagi berfungsi dengan baik, maka ia takut apabila fungsi kontrolnya terganggu.

- Takut Memperlihatkan Bagian Tubuhnya Yang Sakit: Orang sakit seringkali malu dan kadang-kadang merasa terancam ketika memeprlihatkan bagian tubuhnya yang sakit atau cacat kepada dokten dan petugas kesehatan lainnya.

- Rasa Bersalah dan Takut Akan Hukuman: Penyakit atau kecelakaan yang terjadi seringkali dipercayai sebagai sebuah hukuman atau kutukan atas dosa dan kesalahan mereka.

Mengingat adanya beberapa kecemasan dan ketakutan yang dialami oleh orang sakit maka Russel Dicks, seperti dikutip Daniel Susanto, menyatakan beberapa hal yang tidak boleh dilakukan oleh para pelayan pastoral saat melakukan pendampingan atau perkunjungan kepada orang sakit, yaitu sebagai berikut: 45

- Berbicara terlalu banyak

- Tinggal terlalu lama

${ }^{45}$ Daniel Susanto, Perspektif Kristen Pelayanan Pastoral Untuk Orang Sakit, in Mendampingi dengan Hati...., p.12 
- Bertanya pada pasien tentang apa penyakit yang dideritanya, sebab pasien akan menceritakan sendiri penyakit yang dideritanya apabila ia dengan keinginan sendiri menceritakan penyakitnya pada pelayan pastoral.

- Melakukan perdebatan dengan pasien.

- Melakukan pembicaraan tentang orang lain yang menderita penyakit yang sama.

- Memaksa pasien untuk melakukan doa.

- Berdoa yang terlalu panjang.

\section{Persyaratan Ketrampilan}

Para pelayan pastoral yang hendak memiliki ketrampilan yang baik dalam melaksanakan percakapan pastoral dan juga konseling pastoral perlu diperlengkapi dengan beberapa kemampuan atau skills. Adapun untuk di bawah ini beberapa kemampuan yang perlu dimiliki untuk melakukan percakapan pastoral dengan baik adalah sebagai berikut: 46

- Menguasai teknik percakapan pastoral yang efektif, seperti bagaimana memulai, mengembangkan, dan mengakhiri sebuah percakapan pastoral.

- Mendengar dengan penuh perhatian dan berusaha menangkap ekspresi verbal maupun non-verbal dari orang-orang yang dilayani.

- Menerima keberadaan orang yang kita layani sebagaimana adanya.

- Merasakan apa yang dirasakan oleh orang yang dilayani.

- Tidak emosional, tidak mudah terpancing atau berusaha mendominasi percakapan, tidak melakukan khotbah yang menggurui orang yang kita layani.

Sementara itu ada seorang pakar pelayanan pastoral konseling di Indonesia yang bernama Yakub B. Susabda, yang mengemukakan terdapat meliputi enam belas kompetensi/kemampuan atau skill yang harus dikuasai oleh

${ }^{46}$ Daniel Susanto, Perspektif Kristen Pelayanan Pastoral Untuk Orang Sakit, in Mendampingi dengan Hati..., p.13-14 
seorang konselor pastoral, yang bisa diterapkan dalam pelayanan konseling pastoral. Tentunya hal ini sangat sesuai juga dengan persyataran ketrampilan yang harus dimiliki oleh seorang pelayan pastoral. Dibawah ini akan dijabarkan ke enam belas skills atau kemampuan tersebut. ${ }^{47}$

\section{a. Verbal Skill atau Kemampuan Berkomunikasi}

Verbal skill adalah kemampuan berkomunikasi atau berbicara dengan baik, mampu membangun komunikasi dialogis, mampu memilih kata yang tepat, menyusun kalimat yang tepat dan menyampaikan dengan nada yang tepat pula. Mampu menghilangkan hambatan-hambatan seperti terbata-bata, gugup, mudah panik, berputar-putar, mengulang-ulang kalimat, terlalu lirih atau terlalu keras, cenderung menghakimi, menyelidiki dan cenderung terlalu cepat mengumpulkan data dan terlalu cepat menasihati.

Hal yang terutama yang harus diperhatikan dalam kompetensi verbal ini adalah bagaimana pelayan pastoral dapat memilih kata-kata yang menciptakan self-awareness atau kesadaran diri dalam diri pasien sehingga dia mampu mengahadapi realita yang ada. Kemampuan dalam membuka kesadaran diri ini perlu dilatih terus menerus.

\section{b. Awareness of Body Language Skill atau Kemampuan Dalam Mengatur Bahasa Tubuh}

Kompetensi ini adalah mengatur bahasa tubuh dengan baik sedemikian rupa agar menjaga kepekaan terhadap reaksi manusia pada umumnya, dimana reaksi tersebut bisa negatif atau positif. Untuk memperoleh reaksi positif, pelayan pastoral perlu mewaspadai dan sadar akan segala sikap tubuhnya, baik ketika berdiri, duduk, saat menatap, saat menyentuh, menjaga antara pelayan pastoral dengan pasien agar jarak tersebut tidak terlalu dekat atau tidak terlalu jauh.

Selain itu perlu mengamati sikap tubuh pasien apakah sikapnya terus menatap pelayan pastoral, atau terlalu banyak menunduk, kurang perhatian dan lain-lain. Perlu kepekaan dari pelayan pastoral, sehingga pelayan dapat bersikap sebaik mungkin.

${ }^{47}$ Yakub B. Susabda, Menjadi Konselor Profesional, (Yogyakarta: Penerbit Andi, 2007), p.37-52 


\section{c. Observation Skill atau Kemampuan Melakukan Observasi}

Kompetensi untuk melakukan observasi adalah ketajaman pelayan pastoral untuk mengenali siapa orang sakit dan apa yang terjadi di dalam kehidupannya, mampu juga menangkap hal-hal apa saja baik yang disengaja maupun yang tidak disengaja yang sedang dikomunikasikan olehnya.

\section{d. Starting Skill atau Kemampuan Untuk Memulai}

Pelayan pastoral perlu memulai percakapan pastoral dengan baik, seringkali percakapan yang ada adalah percakapan biasa atau basa-basi, sedangkan percakapan pastoral adalah percakapan yang melibatkan emosi yang mana dia sebagai orang sakit mau mencurahkan isi hati atau membagikan perasaannya (share his/her feeling). Starting Skill sebenarnya menciptakan kesiapan emosi dari pasien untuk membuka hati, emosi dan pikirannya.

\section{e. Building Rapport Skill atau Kemampuan Untuk Membangun Relasi}

Setelah pasien siap melakukan percakapan pastoral, pelayan pastoral perlu membangun hubungan atau relasi yang baik, sehingga tercipta kondisi yang kondusif, aman, senang, bisa dipercaya. Pasien dapat merasakan senang karena perasaan dan pikirannya sangat dihargai oleh pelayan pastoral.

\section{f. Responding Skill atau Kemampuan Memberi Tanggapan}

Kemampuan ini adalah bagaimana pelayan pastoral mampu memberi tanggapan dengan tepat untuk setiap kalimat yang diucapkan pasien, kecakapan ini bukan hanya memerlukan kemampuan listening, emphaty, understanding dan acceptance, melainkan juga memiliki kemampuan untuk memilih kata yang tepat, menyusun dalam kalimat yang tepat, serta mengkomunikasikannya dengan nada dan sikap yang tepat pula.

\section{g. Acceptance Skill atau Kemampuan Menerima}

Kemampuan ini adalah kemampuan untuk menerima pasien apa adanya, mampu menghargai dan menerima pasien tanpa syarat, dan tidak jatuh ke dalam sikap menghakimi. Pelayan pastoral diuji kesabarannya untuk tidak cepat 
memberi nasihat, mendikte, mengatur, memberikan resep, dan mengusahakan dengan cepat agar pasien cepat pulih atau sembuh.

\section{h. Listening Skill atau Kemampuan Mendengar}

Kemampuan ini adalah kemampuan untuk dapat menangkap, merasakan, membayangkan, membaca, dan mengerti apa yang dibalik setiap perkataan atau sikap dari pasien. Melalui kemampuan ini pelayan pastoral mampu menangkap apa dan bagaimana pola pikir pasien, pola kerja emosinya, juga mengerti kondisi dan dunianya. Lebih tepatnya kemampuan mendengar ini adalah mendengar dengan hati.

Mendengar dengan hati memungkinkan pelayan pastoral mampu mendengar cry for help atau teriakan minta tolong, mampu mendengar segala kekecewaan, ketakutan bahkan kemarahan pasien terhadap Allahnya sekalipun karena penyakit yang dideritanya.

\section{i. Reflection Skill atau Kemampuan Merefleksikan Apa Yang Telah Didengar}

Kemampuan mendengar akan lebih lengkap apabila ditambah dengan kemampuan merefleksikan apa yang telah ditangkap dalam pendengaran tersebut. Kemampuan ini sebenarnya menjaga percakapan pastoral agar tidak bias, artinya pelayan pastoral tetap pada fokus untuk menciptakan self-awareness atau kesadaran diri dari pasien agar dia tetap memiliki kesadaran yang penuh walau ditengah kondisi yang penuh kesulitan.

\section{j. Focusing Skill atau Kemampuan Untuk Memusatkan Pikiran}

Kemampuan ini adalah kemampuan untuk memusatkan pikiran sehingga menangkap isi berita yang disampaikan, karena seringkali pasien berbicara berpuluh-puluh menit tanpa dapat dipotong, ada puluhan kasus yang ia ceritakan sekaligus, bahkan ia berbicaranya berputar-putar. Pelayan pastoral/konselor perlu memperhatikan gelombang emosi yang clustering around (mengelompokkan pada area-area tertentu), dan memperhatikan tekanan atau pengulangan pada bagian-bagian tertentu dari keluhannya.

\section{k. Intuitive Skill Atau Kemampuan Intuisi}


Kemampuan intuisi dibutuhkan untuk mengenali diri, motivasi, dan tujuan di balik kata, sikap, dan tingkah laku pasien. Apakah orang yang dilayani dapat dipercaya, jujur, rendah hati, peka, atau sebaliknya ia sinis terhadap hal-hal rohani, pendendam dan sebagainya. Semakin trampil seorang pelayan pastoral maka kemampuan intuisi nya semakin matang, kemampuan intuisi tentunya didukung dengan kemampuan memusatkan dan kemampuan observasi. Perlu diwaspadai pula intuisi manusia bisa sangat subjektif, maka perlu diterangi dengan keberadaan Roh Kudus.

\section{l. Understanding Skill Atau Kemampuan Untuk Memahami}

Kemampuan untuk memahami bagaimana pasien berpikir, merasa dan bertingkah laku akan membawa pelayan pastoral pada sikap yang tidak menghakimi (non-judgemental), dan pelayan pastoral terhindar dari sikap sekedar hanya mempersalahkan. Kemampuan ini didukung oleh sikap mendengarkan dan empati sehingga tercipta situasi yang kondusif dan lancar.

\section{m. Emphatic Skill atau Kemampuan Berempati}

Empati adalah kemampuan untuk menaruh kedua kaki kepada orang yang dilayani, sehingga dapat melihat realita hidup dari sudut pandang dia. Pelayan pastoral mampu melihat, merasakan, berpikir sama seperti yang dialami pasien. Kemampuan empati ini biasanya diperoleh lewat "familiarisasi" yaitu pengalaman yang diperoleh atau terasah dengan baik oleh seseorang ketika masa kecilnya ikut merasakan berbagai macam perasaan baik suka dan duka di dalam kehidupan keluarganya.

Empati harus dibedakan dengan simpati, karena simpati adalah adanya keterlibatan atau keterhanyutan emosi atau emotional involvement, sedangkan empati tetap bebas dan mandiri. Pikiran dan perasaan pelayan pastoral tetap objektif meskipun ia ikut merasakan bahkan menghayati kondisi pasien, makanya empati memiliki kekuatan untuk menyadarkan dan menyembuhkan (therapeutic), empati juga dapat menghadirkan hal-hal positif sehingga pasien bisa bangkit dari keterpurukkannya. 


\section{n. Analytic Skill Atau Kemampuan Membuat Analisa}

Kemampuan ini adalah kemampuan untuk melihat komponen-komponen yang membangun timbulnya masalah pada diri pasien, dapat membedakan komponen mana yang merupakan faktor pencetus yang paling kuat, apakah komponen dari luar atau dari dalam pasien tersebut. Kemampuan menganalisa ini, bisa dikembangkan menjadi sesuatu yang profesional apabila pelayan pastoral mau mengembang diri dengan melakukan riset, penelitian, memiliki pengetahuan yang solid bahkan mengambil pendidikan profesi konselor. Ilmu psikologi adalah ilmu yang harus dikuasainya, juga ia terlatih menganalisa kasus-kasus.

Sedangkan untuk pelayanan yang bersifat praktis cukup melakukan percakapan pastoral seperti yang telah dikemukakan di atas. Kemampuan menganalisa sangat berhubungan dengan kemampuan building rapport.

\section{o. Reframing Skill Atau Kemampuan Untuk Memberikan Kerangka/Pola Pikir Yang Baru.}

Kemampuan ini untuk menolong pasien menyadari dan menggunakan kerangka atau pola pikir yang baru dan tepat dalam mengahadapi realita kehidupannya. Frame atau kerangka yang tepat sangat diperlukan, karena seringkali pasien menggunakan kerangka yang terlalu kecil atau terlalu besar, misalnya pada kasus perselingkuhan, pasangan yang menderita akan membuat kerangka berpikir yang salah yaitu dengan mengatakan bahwa perselingkuhan adalah hal yang biasa atau lumrah terjadi pada zaman kini.

Menjadi tugas pelayan pastoral untuk memberikan kerangka pikir yang baru, yang benar dan tepat, hal ini sangat diperlukan karena seringkali pasien tidak dalam kondisi prima sehingga pola pikirnyapun seringkali tergantung pada situasi emosinya yang labil atau tidak positif. Hal penting yang diperlukan oleh pelayan pastoral pada kemampuan reframing ini adalah memiliki kesadaran diri atau self-awareness. Kemampuan reframing inipun sebenarnya memiliki fungsi edukatif karena pasien dapat belajar dari permasalahnnya dan memiliki perfektif yang berbeda dan mampu menggunakan komponen-komponen baru yang mungkin selama ini belum pernah dipergunakannya.

\section{p. Solving Skill Atau Kemampuan Untuk Menyelesaikan Permasalahan}


Kemampuan ini adalah kemampuan untuk menciptakan kondisi yang memungkinkan pasien menyadari dirinya dan menyadari apa yang sedang terjadi dalam hidupnya, serta mampu menemukan jalan keluar dalam menyelesaikan persoalan yang dialaminya. Hal ini terjadi saat dirinya mampu mengaktualisasikan dirinya, dan mampu menghidupkan kembali fungsi normal yang seharusnya ada dalam dirinya yaitu hidup sesuai dengan hukum alam semesta, hukum hati nurani dan hukum Allah.

\section{q. Persyaratan Pertumbuhan Pribadi}

Hal yang dimaksud pertumbuhan pribadi adalah pelayan pastoral perlu memiliki suatu pribadi yang sehat dan kuat. Pribadi yang sehat tentunya adalah pribadi yang memiliki pertumbuhan multidimensional, maksudnya ia menjadi pribadi yang seutuhnya diberbagai bidang kehidupannya.

Ia memiliki kedewasaan spiritual, kematangan emosi, psikis dan sikap, serta tingkah laku yang menjadi contoh atau teladan. Dalam pertumbuhan pribadi yang baik tentunya, ia memiliki pertumbuhan rohani yang baik pula, ia akan menjaga relasinya dengan Tuhan dengan sangat baik, mengingat Tuhan adalah Gembala/Pastor Agung bagi domba-dombaNya, Tuhan adalah Sang Konselor Agung. Para pelayan pastoral perlu memiliki disiplin dalam melakukan waktu/saat teduh, rajin mempelajari Firman Tuhan dan menerapkan dalam kehidupan sehari-hari.

Hubungan atau relasi yang baik dengan Tuhan berdampak pula pada hubungannya dengan sesama, ia mampu mengasihi orang lain, dengan memperlihatkan cinta kasih yang tulus, ikhlas, ramah, karena mustahil pelayanan pastoral dapat dilakukan apabila para pelayannya tidak memiliki pertumbuhan rohani dan pribadi yang baik.

Dalam bukunya yang membahas tentang pertumbuhan rohani, Charles $\mathrm{R}$ Swindoll mengemukakan delapan hal yang penting yang dapat mempengaruhi pertumbuhan rohani seseorang sehingga bisa menjadi pribadi yang saleh dan taat pada Tuhan. Kedelapan hal tersebut adalah sebagai berikut: ${ }^{48}$

\footnotetext{
${ }^{48}$ Charles R Swindoll, So, You Want to Be Like Christ? Anda Mau Menjadi Seperti Kristus?: Delapan Hal Penting Untuk Merealisasikannya, (Bandung: Lembaga Literatur Baptis, 2008), p.1-8.
} 
- Keakraban: memperdalam kehidupan dengan menjaga hidup yang bergaul akrab dengan Tuhan.

- Keserdehanaan: Membenahi pikiran dengan pola hidup sederhana.

- Keheningan dan kesendirian: Perlu memperlambat langkah, ditengah aktifitas manusia modern yang semakin sibuk dengan jadwal yang padat.

- Penyerahan: Melepaskan genggaman, menyerahkan semuanya pada Kristus.

- Doa: Berseru pada Allah

- Kerendahan Hati: Menunduk pada otoritas Allah

- Pengendalian Diri: Menahan diri agar tidak jatuh dalam jebakan dosa.

- Pengorbanan: Menyerahkan diri sepenuhnya.

\section{Pengertian Kesembuhan Berdasarkan Ilmu Pengetahuan atau Sekuler.}

Menurut pandangan seorang dokter yang juga terjun ke dalam pelayanan misi penginjilan di Benua Afrika, dr. Daniel Fountain bahwa:

Dalam pemikiran sekuler, orang sakit tidak dipandang sebagai manusia seutuhnya. Ia hanya dipandang sebagai "pasien" dan dijadikan obyek studi dan perawatan. Kemajuan ilmu pengetahuan tentang tubuh dan psike manusia menghasilkan peningkatan spesialisasi. Kita memisah-misahkan seorang sakit menjadi bagian-bagian yang terpenggal-penggal sehingga kita hanya mengobati lever yang sakit, tumor di paruparu atau usus buntu yang pecah. Spesialisasi itu sendiri baik dan tak terhindari, tetapi hilangnya keutuhan seorang manusia tidak baik dan seseungguhnya dapat dihindari. ${ }^{49}$

Selain mengkritisi bahwa hilangnya keutuhan sebagai kelemahan yang pertama dalam pelayanan kesehatan secara sekuler, Fountain juga menambahkan bahwa pelayanan kesehatan dalam pemikiran sekuler dan dunia medis banyak mempunyai kelemahan-kelemahan lain: Kedua, hilangnya jalinan hubungan manusiawi karena

\footnotetext{
${ }^{49}$ Bandingan Pendapat dokter Daniel E Fountain, Kesehatan Alkitab dan Gereja, (Bandung: Lembaga Literatur Baptis, 2003), 79-103
} 
pasien hanya dipandang sebagai objek semata, dokter dan pekerja medis lain diajarkan untuk bersikap netral sehingga tidak hubungan timbal balik.

Ketiga, tidak adanya kesadaran tentang Roh Manusia, roh manusia adalah bagian dari diri manusia yang sadar akan keberadaan Tuhan, yang menuntun manusia untuk memahami arti hidup namun karena ilmu pengetahuan sulit menjangkau alam roh maka seringkali diabaikan. Keempat, hilangnya nilai kehidupan manusia, karena nilai kehidupan manusia menjadi relatif, bergantung pada potensinya daam berkarya di masyarakat. Apabila tidak dapat berkontribusi maka mereka disisihkan, hal ini juga memicu praktek aborsi dan euthanasia. Kelima, tidak adanya tujuan akhir, maksudnya menghindari isu tentang kematian, karena kematian dihindari dan ditakuti. Keenam, sekulerisasi kesehatan masyarakat, Fountain mengkritisi sistem kapitalisasi karena hanya mengeksploitasi masyarakat sebagai sumber ekonomi semata. ${ }^{50}$

Dari pernyataan di atas pengertian kesembuhan dalam pandangan sekuler banyak mengandung kelemahan, seperti hanya berfokus pada unsur badaniah dan psikologis, namun tidak melibatkan unsur rohani, bahkan manusia hanya dipandang secara parsial tidak secara utuh, dan ada beberapa kelemahan-kelemahan lain seperti yang diungkapkan oleh dr. Fountain. ${ }^{51}$

\section{Kelemahan-kelemahan dari Pengertian Kesembuhan dari Sudut Pandang Sekuler}

Seorang dokter Kristiani yang sungguh-sungguh peduli terhadap pelayanan kesehatan bernama Daniel Fountain, juga beliau adalah seorang misionaris kesehatan, seorang praktisi yang terjun langsung di lapangan pelayanan kesehatan, dan banyak melayani di berbagai negara termasuk khususnya di Afrika di mana beliau cukup lama melayani, ia menemukan banyak kelemahan dari pelayanan kesehatan masa kini yang didasarkan pada prinsip sekuler atau umum. Di bawah ini akan dijelaskan kelemahankelemahan tersebut seperti yang dijelaskan di dalam buku karangannya yang berjudul: "Kesehatan, Alkitab dan Gereja”.

\section{1). Hilangnya Keutuhan Manusia} 86.

${ }^{50}$ Daniel E Fountain, Kesehatan Alkitab dan Gereja, (Bandung: Lembaga Literatur Baptis, 2003), 79${ }^{51}$ Ibid 
Dalam pelayanan medis secara umum yang ditekankan adalah pelayanan di mana pasien atau manusia ditempatkan hanya sebagai objek saja, ilmu pengetahuan tentang medis memang menghasilkan banyak kemajuan seperti spesialisasi, tetapi manusia dipandang sebagai bagian yang terpisah-pisah, atau terpenggal-penggal. Misalnya dokter memandang pasien dengan mengobati levernya yang sakit, tumor di paru-parunya, atau adanya usus buntu yang pecah, namun tidak melihat kepribadian dari pasien tersebut.

Walau tidak dapat disangkal bahwa spesialisasi adalah sesuatu yang baik dan tak dapat dihindari, tetapi hilangnya keutuhan seorang manusia tidak baik karena pasien hanya dilihat sebagai objek saja. Hubungan antara pasien dan dokter menjadi hubungan yang transaksional dan bukan suatu hubungan yang bersifat kemanusiaan yaitu timbal balik. ${ }^{52}$

\section{2). Hilangnya Jalinan Hubungan Antar Sesama Manusia}

Konsep pelayanan kesehatan yang terlalu bersifat individualistis dan objektifitas seringkali menjadi kendala, karena memisahkan pasien dengan konteks keluarga dan hubungan sosial. Misalnya stres adalah faktor pemicu utama yang melatar-belakangi adanya sakit, dan dibalik stres itu sendiri kemungkinan terdapat masalah hubungan antar personal, namun sayangnya seringkali para pelayan kesehatan jarang memikirkan persoalan tersebut secara mendalam. Kalaupun memikirkan seringkali dilakukan dengan cara yang kurang memadai.

Konsep tentang pengampunan, tentang rekonsialisasi yang radikal seringkali dilupakan bahkan terasa asing dalam pemikiran umum pelayanan kesehatan. Karena alasan hubungan antar personal sulit diukur maka dianggap kurang ilmiah, sehingga keluarga dan konteks social tidak dipandang sebagai faktor etiologis atau penyebab dari suatu penyakit, sehingga proses penyembuhan seringkali mengabaikan faktor-faktor tersebut.

\section{3). Tidak Adanya Kesadaran Tentang Keberadaan Roh Manusia}

52 Daniel Fountain, Kesehatan, Alkitab,dan Gereja,(Bandung: Lembaga Literatur Baptis,2003), p.78-79. 
Roh manusia sebenarnya adalah bagian dari kehidupan manusia yang paling hakiki dimana bagian ini dapat mejadi alat komunikasi antara manusia dengan Tuhan Sang Pencipta, di dalamnya manusia sadar akan tujuan dan hidup bahkan sampai pada tujuan akhir dari kehidupan itu sendiri. Pandangan umum di dunia kesehatan seringkali menyangkal keberadaan roh tersebut karena tidak terjangkau oleh ilmu pengetahuan. Seringkali Tuhan menjadi tidak relevan dalam hal kesembuhan dan kesehatan, dibalik keberadaan penyakit tidak ada hubungannya dengan arti dan tujuan hidup. Padahal tujuan hidup yang hakiki sangat berhubungan dengan harapan seseorang.

Pandangan duniawi seringkali melupakan atau tidak melibatkan tujuan hidup manusia yang paling hakiki dan harapan manusia dalam proses pemulihan, padahal seringkali orang-orang yang mempunyai kepercayaan rohani terhadap Tuhan ketika melibatkan Tuhan dalam seluruh aspek kehidupannya akan mendukung dalam proses penyembuhannnya. ${ }^{53}$

\section{Pengertian Kesembuhan/Kesehatan Berdasarkan Alkitab}

Erhard Schneider menjelaskan bahwa penyakit sebenarnya tidak ada pada penciptaan awal dari manusia dan alam semesta kita oleh Tuhan Allah, penyakit timbul kemudian karena kejatuhan manusia dalam dosa, manusia mengalami banyak kesulitan termasuk penyakit karena bentuk konsekuensi kejatuhan manusia ke dalam dosa. Kematian adalah bentuk hukuman atas dosa, dan penyakit sebenarnya adalah proses menuju kematian tersebut. ${ }^{54}$ Walaupun demikian Schneider tidak menampik bahwa penyebab penyakit bisa juga dikarenakan faktor gangguan di organ-organ tubuh manusia, seperti gangguan metabolism, hormonal dan lain-lain. ${ }^{55}$

Untuk mendefinisikan penyakit tidak bisa lepas dari pengaruh filosofi yang di anut dua bangsa/kebudayaan yang berpengaruh pada pemahaman awal penyakit seperti yang dinyatakan di dalam Alkitab. Kedua bangsa/kebudayaan tersebut adalah bangsa Ibrani/Yahudi dan Yunani. Bagi bangsa Ibrani manusia itu utuh, terintegrasi dalam satu kesatuan, sedangkan bangsa Yunani memandang manusia secara parsial yaitu tubuh jasmaniah/badaniah dengan rohaniah. Perlu diketahui pula perkembangan dunia medis

\footnotetext{
${ }^{53}$ Daniel Fountain, Kesehatan, Alkitab,dan Gereja ..., p.78-79.

${ }^{54}$ Erhard Schneider, Maukah Engkau Sembuh...., p.5

${ }^{55}$ Ibid., p. 8-9.
} 
banyak dipengaruhi oleh kedua budaya tersebut, sebelum akhirnya berkembang pesat di budaya barat dan berkembang ke seluruh dunia.

Pada intinya Schneider mengingatkan kembali bahwa berbicara mengenai sakit, jangan lupa di dalamnya ada unsur dosa, namun harus hati-hati juga bahwa tidak selalu semua penyakit disebabkan dosa, melainkan oleh faktor-faktor yang murni dari aspek yang berhubungan dengan tubuh seperti faktor organ-organ tubuh, metabolisme dan hormonal tubuh.

Kesembuhan/kesehatan berdasarkan prinsip Alkitab tentunya memakai Alkitab sebagai dasar utama dalam membuat pengertiannya. Walaupun memakai Alkitab sebagai dasar, umat Kristen sendiri mendefinikan kesembuhan/kesehatan dengan banyak paradigma sesuai dengan teologi, denominasi yang dianutnya. Istilah yang dipakai pun bermacam-macam misalnya: Kesembuhan karena Iman, Kesembuhan karena Mujizat, Kesembuhan Supernatural, 56 dan yang paling terkenal adalah kesembuhan Ilahi.

Menurut dokter Fountain sebagai praktisi kesehatan Kristen, dalam mendefinisikan kesehatan berdasarkan Alkitab, harus memperhatikan hal-hal berikut: Pertama, Allah adalah Pencipta semesta, Ia berdaulat penuh, Ia maha baik, Pemberi kehidupan dan kesehatan. Kedua, Dunia yang diciptakan Allah adalah baik, namun manusia diberi tanggung jawab untuk mengelolanya. Ketiga, Manusia menyandang citra Allah di dunia, maka harus saling memperdulikan, menyayangi, dan saling menolong dalam komunitasnya. Keempat, Kejahatan merupakan penyimpangan dari rencana Allah, suatu kekuatan yang ingin menghancurkan ciptaan Allah, dan harus diperangi oleh manusia dengan pertolongan Allah. Kelima, terdapat hubungan kesehatan dengan perilaku manusia. Keenam, Yesus Kristus, Anak Allah, datang untuk memulihkan manusia seutuhnya, Ia menunjukkan prinsip-prinsip dasar pelayanan kesehatan dan pemulihan. ${ }^{57}$

Pada dasarnya kesembuhan yang sesuai dengan prinsip Alkitabiah adalah pemulihan manusia seutuhnya terutama pemulihan yang dilakukan oleh Tuhan Yesus. Lubang-lubang kelemahan dalam pengertian kesembuhan secara sekuler atau medis ditutup sempurna oleh Alkitab karena Alkitab mampu memandang manusia seutuhnya

\footnotetext{
${ }^{56}$ J. Sidlow Baxter, Divine Healing Of The Body, (Grand Rapids, Michigan: Zondervan Publishing House, 1979), 18-24.

${ }^{57}$ Daniel E Fountain, Kesehatan Alkitab dan Gereja, (Bandung: Lembaga Literatur Baptis, 2003), 92.
} 
dengan lengkap. Hal ini dimaklumi karena pandangan sekuler termasuk ilmu pengetahuan medis di dalamnya pastilah mengandung banyak kelemahan, terdapat indikasi bahwa ilmu pengetahuan medis telah bergeser dari pandangan Alkitab, namun hal inipun bukan berarti menaifkan peran ilmu pengetahuan tersebut. Justru ini adalah tantangan untuk manusia dan ilmu pengetahuannya terus berusaha dikembangkan tentunya dengan meminta hikmat dan pertolongan dari Tuhan dan Firman-Nya. Maka menurut peneliti ada pandangan ketiga seperti yang akan dibahas pada penjelasan di bawah ini.

\section{Pengertian Kesembuhan/Kesehatan Berdasarkan Perpaduan Ilmu Pengetahuan dan Alkitab}

Pada dasarnya pengertian ini adalah berusaha memadukan pandangan sekuler atau ilmu pengetahuan medis dengan Alkitab, tanpa bermaksud mengkontraskan atau mempertentangkan keduanya. Pandangan ini adalah mengambil manfaat dari pandangan sekuler atau ilmu pengetahuan, bahkan menghargainya sebagai usaha manusia untuk bertanggung jawab dalam mengelola dunia ini seperti yang diinginkan oleh Tuhan. Seraya manusia juga tidak melupakan peran Allah yang Maha Kuasa dalam mengusahakan kehidupan yang sehat, dan manusia tidak boleh juga melupakan bahwa ada kuasa kegelapan yang menyebabkan penyakit yang harus dilawan. Manusia sebagai makhluk ciptaan Tuhan yang diciptakan serupa dengan gambar Allah atau Imago Dei tidak boleh pasrah, dalam melawan kuasa kegelapan/kejahatan termasuk penyakit tersebut, manusia memerlukan pertolongan dari Sang Maha Kuasa, Sang Maha Penyembuh, yaitu Tuhan Yesus.

\section{Kesembuhan/Kesehatan Identik dengan Menjadi Manusia Seutuhnya}

Dalam usaha untuk mencapai kesembuhan atau kesehatan, yang membuat kebahagiaan, kesejahteraan, kesempurnaan bagi setiap orang, tentunya adalah impian setiap insan di muka bumi ini. Dari berbagai penjelasan di atas baik dari pengertian yang dikemukakan oleh lembaga tingkat dunia seperti WHO, lalu pengertian dari tingkat nasional melalui Undang-Undang Kesehatan, menjelaskan bahwa definisi sehat adalah bagaimana usaha untuk menjadi manusia seutuhnya, lalu dari pengertian berdasarkan 
ilmu pengetahuan/ sekuler dan dari sudut pandang Alkitab. Maka terjadi satu muara yaitu konsep/pengertian tentang manusia seutuhnya.

Pengertian manusia seutuhnya di dalam pengertian sekuler memang diakui sudah baik karena menyentuh berbagai aspek seperti kesinambungan pelayanan kesehatan mulai dari bayi sampai lanjut usia, faktor lingkungan, faktor sosial-ekonomi, faktor politik, pendidikan dan indicator-indikator yang ditetapkan oleh Badan Kesehatan Dunia (WHO). 58

Namun dari definisi tersebut sama sekali tidak mempertimbangkan aspek rohani, sehingga diperlukan adanya hal-hal rohani yang perlu ditambahkan pada definisi lembaga-lembaga dunia tersebut, yang menurut sebenarnya sudah bagus namun perlu ditambahkan agar menjadi lengkap. Tambahan dari definisi manusia seutuhnya tersebut adalah sebagai berikut:

\section{a. Manusia Yang Berdamai Dengan Allah}

Tanpa perdamaian dengan Allah, maka manusia tidak akan mencapai kesembuhan, kesehatan atau kebahagiaan. Manusia yang berdamai dengan Allah adalah manusia yang hidup sesuai dengan rencana Allah. Manusia dapat berdamai dengan Allah melalui Tuhan Yesus karena karyaNya menebus dosa manusia maka perdamaian terjadi, tanpa Yesus Kristus maka tidak mungkin manusia menjadi utuh. Rencana Allah bagi manusia adalah baik, namun kuasa dosa menghancurkan rencana baik tersebut, tetapi pemulihan terjadi ketika Tuhan Yesus mengalahkan kuasa dosa tersebut. Jadi manusia yang seutuhnya haruslah manusia yang menerima Tuhan Yesus sebagai pendamai, pemulih, penebus dosanya. Tanpa kehadiran Yesus Kristus maka manusia tidak pernah bisa mencapai keutuhannya. ${ }^{59}$

\section{b. Manusia Yang Berdamai Dengan Sesama.}

\footnotetext{
${ }^{58}$ Bandingkan dengan Suistainable Development Goals (SDGs) atau Indeks Pembangunan Manusia IPM mengukur pencapaian rata-rata sebuah negara dalam 3 dimensi dasar pembangunan manusia:

- $\quad$ hidup yang sehat dan panjang umur yang diukur dengan harapan hidupsaat kelahiran

- $\quad$ Pengetahuan yang diukur dengan angka tingkat baca tulispada orang dewasa (bobotnya dua per tiga) dan kombinasi pendidikan dasar, menengah, atas gross enrollment ratio (bobot satu per tiga).

- $\quad$ standard kehidupan yang layak diukur dengan logaritma natural dari produk domestik brutoper kapita dalam paritasi daya beli. (https://id.wikipedia.org/wiki/Indeks_Pembangunan_Manusia) diakses 06 Desember 2017.

${ }^{59}$ Bandingkan dengan pendapat Erhard Schneider, Maukah Engkau Sembuh?. Batu: YPPII: Departemen Literatur, 1992), dan dr. Daniel E Fountain, Kesehatan, Alkitab \& Gereja. (Bandung: Lembaga Literatur Baptis, 2003)
} 
Setelah mengalami perdamaian dengan Allah, manusia perlu mengalami perdamaian dengan sesama. Permusuhan, pertikaian dengan sesama dapat mengakibatkan banyak masalah termasuk penyakit, perdamaian dengan manusia harus dilandasi dengan sikap mau mengampuni, memaafkan, dan mempunyai hati yang luas untuk mampu menerima keberadaan sesama walau banyak ada diantara mereka yang berbeda dan tidak disukai oleh kita. Kerendahan hati, sikap toleransi yang tinggi juga diperlukan di dalam kehidupan yang penuh keberagaman ini. Keberagaman hidup manusia hendaknya diterima sebagai sebuah kekayaan yang saling melengkapi satu sama lain.

\section{c. Manusia Yang Mampu Menerima Penderitaan Sakit Sebagai Cara Tuhan Untuk Mendewasakannya}

Manusia yang seutuhnya adalah manusia yang mampu menerima penderitaan sakit sebagai sebuah cara/jalan Tuhan untuk lebih mendewasakannya, sehingga manusia tersebut lebih kuat dalam menghadapi berbagai persoalan. Manusia sebagai makhluk ciptaan tentunya tidak mungkin melebihi Sang Penciptanya, banyak hal dalam hidup ini yang sulit untuk dipecahkan karena keterbatasan manusia, walaupun manusia sudah berusaha secara maksimal, termasuk penderitaan sakit, buktinya masih banyak penyakit yang belum ditemukan obatnya sampai sekarang seperti penyakit kanker, AIDS, dan penyakit lainnya. Manusia seutuhnya adalah manusia yang sadar bahwa ia terbatas, ia adalah makhluk ciptaan yang tidak mungkin melampaui Penciptanya. Keterbatasan ini jangan dipandang sebagai alasan untuk kita berhenti berusaha, justru sebaliknya kesadaran akan keterbatas membuat kita terus belajar dan berusaha sambil memohon pertolongan Tuhan.

Contoh manusia yang mampu menerima penderitaan sakit sebagai hal yang mendewasakannya adalah seorang bernama Nick Vujicic, ia terlahir dalam keadaan cacat tanpa tungkai lengan dan kaki, namun setelah bergumul dengan kelemahan fisiknya justru ia memakai kelemahan fisiknya sebagai sebuah kesaksian untuk memotivasi orang lain, bahkan saat ini ia sudah berkeliling ke 57 negara dan berceramah di hadapan kurang lebih 400 juta orang. Saat ini ia sudah 
mendirikan lembaga pelayanan nirlaba internasional, Life Without Limbs, dan memiliki perusahaan pembuat motivasi, Attitude Is Altitude.60 Juga terdapat tokoh lainnya seperti Joni Erickson Tada61 yang dalam kelemahannya atau dalam kesakitannya bisa berbalik menjadi pribadi yang tangguh, kuat dan dewasa.

\section{d. Manusia Yang Mampu Mewujudkan Perdamaian dan Cinta Kasih Di Lingkungannya.}

Maksud dari pernyataan ini adalah keberadaan manusia yang sebenarnya mampu menghadirkan perdamaian dan cinta kasih dalam bentuk manusia tersebut memiliki kemauan untuk saling mengasihi, mencintai, memperdulikan, memperhatikan, menolong, mencintai, membantu, mendampingi, mengubah, dan menumbuhkan hakikat dasar dari keberadaan manusia yang penuh peradaban, sesuai dengan rencana Tuhan, di dalam lingkungannya. ${ }^{62}$ Dimulai dari lingkungan terkecil yaitu keluarga, kota, bangsa, bahkan seluruh dunia. Bila hal ini terwujud maka akan terbentuk dunia yang damai dan penuh cinta kasih.

\section{Membangun Model Pelayanan Pastoral Konseling Terhadap Orang Sakit Secara} Alkitabiah, Khususnya Di Dalam Injil Lukas 10:33-35

Dikarenakan kebutuhan yang sangat mendesak yaitu perlunya model pelayanan konseling yang Alkitabiah dan aplikatif, maka perlu dibangun satu model pelayanan pastoral konseling terhadap pasien/orang sakit yang bisa diterapkan di masa kini. Maka penulis berusaha membuat model pelayanan berdasarkan pada satu teks di Alkitab yang sangat terkenal dan seringkali digunakan dalam pelayanan terhadap pasien di rumahrumah sakit, khususnya rumah-rumah sakit Kristen.

Adapun teks yang sangat terkenal tersebut adalah perumpamaan tentang orang Samaria yang Baik Hati yang terdapat di dalam Injil Lukas 10:33-35, yang isinya sebagai berikut ini:

33 Lalu datang seorang Samaria, yang sedang dalam perjalanan, ke tempat itu; dan

\footnotetext{
${ }^{60} \mathrm{http}: / /$ www.nickvujicic.com diakses 01 Desember 2017.

${ }^{61}$ www.joniandfriends.org

${ }^{62}$ Bandingkan dengan pendapat Totok S. Wiryasaputra \& Rini Handayani, Pengantar Kedalam Konseling Pastoral, (Salatiga: Asosiasi Konselor Pastoral Indonesia, 2013), 1.
} 
ketika ia melihat orang itu, tergeraklah hatinya oleh belas kasihan.

34 Ia pergi kepadanya lalu membalut luka-lukanya, sesudah ia menyiraminya dengan minyak dan anggur. Kemudian ia menaikkan orang itu ke atas keledai tunggangannya sendiri lalu membawanya ke tempat penginapan dan merawatnya.

35 Keesokan harinya ia menyerahkan dua dinar kepada pemilik penginapan itu, katanya: Rawatlah dia dan jika kaubelanjakan lebih dari ini, aku akan menggantinya, waktu aku kembali.

\section{Struktur Teks Lukas 10:33-35}

Menurut Boland ada kemungkinan Yesus menceritakan cerita ini karena pada waktu itu terjadi pembegalan yang hebat, menurut cerita kuno peristiwa itu terjadi di tengah jalan antara Yesusalem dan Yerikho, di tinkungan lembah Sungai el-Kelt. Kondisi tempat itu sangat baik untuk para penyamun melakukan pembegalan, dalam jarak dua puluh tujuh kilometer antara Yerusalem ke Yerikho, jalannya menurun ratusan meter dan banyak gua untuk persembunyian para penyamun. 63

Di daerah Yerikho terdapat para Imam dan orang Lewi atau para rohaniwan pada waktu itu, imam adalah kelompok atas rohaniwan, dan kaum Lewi kelompok bawah rohaniwan,yang justru menunjukkan sikap tidak peduli berbeda dengan seorang awam barangkali seorang saudagar/pedagang yang mengejutkan orang Yahudi dia adalah seorang Samaria. Justru dia menunjukkan belas kasihan pada orang yang mengalami pembegalan tersebut. 64

Sedangkan menurut Howard Marshall, teks ini berisi argumentum ad hominem yang artinya argumentasi terhadap manusia, hal ini mengacu pada pertanyaan seorang ahli taurat Yahudi mengenai "kepada manusia" dalam terminasi untuk memenuhi hukum yang terutama. Yesus mengatakan perumpamaan ini tentang jalan kehidupan ( a way of life), melainkan bagaiman/cara untuk hidup ( a way to life), bagaimana cara memperlakukan manusia dalam persfektif yang benar sesuai prinsip Alkitab. ${ }^{65}$

${ }^{63}$ B.J. Boland \& P.S. Naipospos, Tafsiran Injil Lukas..., p.271

${ }^{64}$ B.J. Boland \& P.S. Naipospos, Tafsiran Injil Lukas..., p. 272 122.

${ }^{65}$ J. Howard Marshall, Luke: Historian And Theologian, (Exeter, UK: The Paternoster Press, 1978)., p. 
Mengenai Injil Lukas dan hubungannya dengan dunia medis telah ditulis oleh Annete Weissenrieder, yang diterjemahkan dalam bahasa Inggris oleh J.C.B. Mohr, di dalam buku ini membahas bagaimana persepsi dan konstruksi tentang penyakit, tentang pengobatan secara sains/ilmiah, lalu membahas tentang kesembuhan, dan membahas dengan detail mengenai narasi-narasi di Injil Lukas yang membahas tentang kesehatan secara lengkap baik kesehatan yang berhubungan tentang kesehatan masyarakat, sosial, kesehatan wanita hamil, kesehatan anak dan lain-lain. ${ }^{66}$

David Iman Santoso mengemukakan bahwa Lukas dalam aplikasinya menekakankan pemberitaan kepada orang miskin dan orang yang lemah, seperti kaum wanita, para pemungut cukai, dan orang-orang Samaria. ${ }^{67}$

Michael Wilcock, menyebutnya teks ini sebagai argumentum ad hominem, atau argument to man,artinya sebuah argumentasi untuk menjawab pertanyaan seorang ahli Taurat tentang terminasi sesama manusia yang mengacu pada Hukum Taurat, sehingga tercapainya hisup yang kekal, dan Yesus menjawab lakukanlah hal-hal ini maka akan meperoleh hidup yang kekal.68

Howard Marshall memasukkan teks Lukas 10:33-35 ini kedalam salah satu bagian dari karakteristik para murid Kristus, di bawah ini struktur yang dibuat oleh Howard:69

The Characteristics of Disciples / Karakter-karakter Para Murid (10:25-11:13):

- $\quad$ Pertanyaan Dari Seorang Ahli Taurat $\quad$ 10:25-28

- $\quad$ Orang Samaria Yang Baik Hati $\quad$ 10:29-37

- $\quad$ Melayani Yesus 10:38-42

- $\quad$ Doa Bapa Kami $\quad 11: 1-4$

- $\quad$ Sahabat di Waktu Tengah Malam 11:5-8

${ }^{66}$ Annette Weissenrieder, (J.C.B. Mohr - Penerjemah), Images of Illness in the Gospel of Luke: Insights of Ancient Medical Texts, (Tubingen: Wissenschaftliche Untersuchungen zum Neuen Testament 2. Reihe, 2003), p.vi-xii. p.97-99.

${ }^{67}$ David Iman Santoso, Theologi Lukas: Intisari dan Aplikasinya, (Malang: Literatur SAAT, 2006),

${ }^{68}$ Michael Wicock, The Savoir Of The World: The Massage of Luke's Gospel, (Illionis: InterVarsity Press, 1979), p.122-123

${ }^{69}$ Howard Marshall, The Gospel of Luke: A Commentary on the Greek Text, (Grand Rapids Michigan: William B Eerdmans, 1978), p.439-469. 
- $\quad$ Dorongan Untuk Berdoa 11:9-13

Sedangkan John Noland merumuskan struktur dari teks ini termasuk kedalam judul mengasihi Tuhan dan mengasihi sesama, berikut ini adalah struktur yang ia buat: ${ }^{70}$

Mengasihi Allah dan Sesama (10;25-42)

- $\quad$ Bagaimana saya memperoleh hidup yang kekal (10:25-42)

- $\quad$ Siapakah sesama manusia itu? (10:29-37)

- $\quad$ Satu hal yang terpenting (10:38-42)

Charles H Talbert mengemukakan bahwa bagian teks termasuk ke dalam arahanarahan Tuhan Yesus untuk menerapkan cara surgawi dalam kehidupan manusia, setelah menjelaskan harga yang harus dibayar oleh seorang murid, maka Tuhan Yesus melanjutkan dengan bagimana cara mengasihi Tuhan dan mengasihi sesama manusia. ${ }^{71}$

R.A Jaffray membagi teks perumpamaan Orang Samaria yg murah hati menjadi empat bagian sebagai berikut: ${ }^{72}$

- $\quad$ Orang yang bertemu dengan penyamun itu adalah orang berdosa (ayat 30)

- $\quad$ Penyamun yang merampok dan memukul orang itu adalah seteru (ayat 30)

- $\quad$ Imam dan orang Lewi itu menggambarkan guru yang berpura-pura (ayat $31,32)$

- $\quad$ Orang Samaria uang murah hati itu menggambarkan Yesus Kristus Sendiri (ayat 33-35)

Sedangkan menurut Joel B Green memberikan struktur yang lebih detail lagi, bahwa perumpamaan Samaria yang baik hati ini, sebenarnya masih masuk ke dalam konteks pengarahan Yesus kepada para murid yang jumlahnya tujuh puluh. Tuhan Yesus ingin agar murid-muridnya melakukan pelayanan yang excellent, berbeda jauh dengan yang dilakukan oleh para ahli taurat. Hal yang terpenting atau kata kuncinya adalah karakter "berbelas-kasihan" yang harus nampak dalam diri murid Kristus, ketika ahli

\footnotetext{
${ }^{70}$ John Nolland, Word Biblical Commentary: Volume 35b, (Dallas Texas: Word Books Publisher, 1993. p. $578-598$.

${ }^{71}$ Charles H Talbert, Reading Luke: A Literary and Theological Commentary On The Third Gospel, (New York: The Crossroad Publishing Company, 1984), p 124-125.

${ }^{72}$ R.A. Jaffray, Perumpamaan Tuhan Yesus, (Bandung: Yayasan Kalam Hidup, 2000), p.146
} 
Taurat mengatakan "Siapakah sesamamu" jawabannya terbagi jelas dengan dua kategori "musuh" dan "teman". 73

Menurut Joel B Green struktur teks perumpamaan orang Samaria yang baik hati ini, terdiri dari narasi-narasi ini yang terdapat dua bagian pararel sebagai berikut: ${ }^{74}$

\begin{tabular}{|l|l|l|}
\hline & Bagian I & Bagian II \\
\hline Identifikasi Motivasi Ahli Taurat & Ayat 25 & Ayat 29 \\
\hline Pertanyaan Ahli Taurat & Ayat 25 & Ayat 29 \\
\hline Jawaban Yesus dan Pertanyaan Umpan Balik & Ayat 26 & Ayat 30-36 \\
\hline Jawaban Ahli Taurat Sesuai Umpan Balik & Ayat 27 & Ayat 37a \\
\hline Kata Terakhir Yesus yang Berupa Kalimat Perintah & Ayat 28 & Ayat 37b \\
\hline
\end{tabular}

Tampaknya dari pendapat para ahli tersebut terdapat beberapa titik temu yaitu tentang misi Tuhan Yesus datang ke dunia untuk mengubah mindset manusia dalam mengasihi Tuhan dan sesama, yang berbeda jauh dengan konsep dunia yang membedakan sehingga terbentuk karakter murid Yesus yang mengasihi sesama manusia yang berbeda jauh atau sangat kontras dengan cara mengasihi sesama manusia cara dunia yang sering membeda-bedakan baik secara kesukuan, agama, kepercayaan, status sosial, ekonomi dan lain-lain.

Menurut peneliti sendiri struktur teks Lukas 10:33-35 ini dalam konteks mengasihi sesama manusia dengan cara Surgawi yang dijelaskan melalui perkataan Tuhan Yesus, bahkan sesama manusia tersebut dalam kondisi sakit parah dan sangat memerlukan pertolongan adalah sebagai berikut:

- $\quad$ Pelayanan yang memandang sesama sebagai subyek (ayat 33)

- $\quad$ Pelayanan proaktif (ayat 33)

- $\quad$ Pelayanan holistik (ayat 34)

\footnotetext{
${ }^{73}$ Joel B Green, The Gospel of Luke, (Grand Rapids, Michigan: William B Eerdmans Publishing Company, 1997), p.425.

${ }^{74}$ Ibid, p.427
} 
- $\quad$ Pelayanan totalitas (ayat 35)

Pelayanan Sinergitas Antara Allah dengan Manusia (ayat 33-35)

\section{Eksegese Lukas 10:33-35}

\section{Pelayanan Yang Memandang Sesama Sebagai Subyek (ayat 33)}

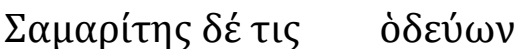

$\tilde{\eta} \lambda \theta \varepsilon \nu \kappa \alpha \tau^{\prime}$

orang Samaria mengadakan perjalanan datang ketempat itu

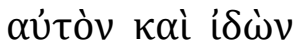

$\varepsilon \dot{\varepsilon} \sigma \pi \lambda \gamma \gamma \vee \operatorname{r} \sigma \theta \eta$

dia melihat dengan matanya sendiri

dan tergeraklah oleh belas-kasihan

Dalam ayat ini, kata kerja yang pertama muncul ò $\delta \varepsilon v ́ \omega v$ dalam bentuk present aktif dan partisif yang berarti bepergian, atau mengadakan perjalanan. Subjek yang melakukan perjalanan tersebut adalah $\Sigma \alpha \mu \alpha \rho i ́ t \eta s$, orang Samaria. Lalu kata kerja yang kedua $\tilde{\eta} \lambda \theta \varepsilon v$ dari kata $\varepsilon^{\prime} \rho \chi \mu \mu \alpha$ เ aorist aktif indikatif, artinya orang Samaria melakukan kegiatan yang bersifat aktif dan partisifatif yaitu mendatangi, lalu setelah mendantangi orang Samaria itu melihat, yaitu dari kata kerja aorist aktif partisif $\mathfrak{\delta} \delta \dot{\omega} v$; artinya melihat. Dimana orang Samaria melihat orang yang terluka oleh penyamun dan mendatanginya karena tergeletak di tengah jalan dimana dia melewati jalan tersebut.

Lalu ada kata kerja berikutnya yaitu kata kerja aorist parstisif $\varepsilon \dot{\varepsilon} \sigma \pi \alpha \gamma \chi v i ́ \sigma \theta \eta$ kata kerja ini adalah kata kerja yang sangat penting karena menjadi inti dari tindakan orang Samaria tersebut yang artinya oleh LAI (Lembaga Alkitab Indonesia) Terjemahan Baru adalah "tergeraklah hatinya oleh belas kasihan", namun terdapat arti lain yang lebih dalam yaitu perasaan atau keinginan untuk memindahkan seluruh hatinya pada orang tersebut.

Dari ketiga kata kerja tersebut nampak inisiatif dari orang Samaria, mulai dari melihat lalu mendatangi orang yang terluka tersebut disebabkan oleh keingnan dia untuk mau memindahkan hatinya kepada orang tersebut. Jadi bisa diterjemahkan ayat 33 ini sebagai berikut: Ketika seseorang Samaria sedang ada dalam perjalanan, ia melihat dengan mata kepalanya sendiri, lalu mendatangi 
orang (yang luka-luka karena diserang penyamun), maka ia seolah-olah ingin memindahkan isi yang ada di dada (hatinya) kepada orang tersebut, karena ia merasa berbelas kasih dan mencintainya.

Tindakan yang dilakukan oleh orang Samaria mulai dari melihat, mendatangi adalah dikarenakan rasa mencintai, menyayangi dari kata Yunani $\sigma \pi \lambda \alpha \gamma \chi \nu \iota \zeta o \mu \alpha \iota$ yang menjelaskan bagimana orang Samaria tersebut memperlakukan sesamanya manusia bukan sebagai objek atau benda semata, melainkan memperlakukannya seperti dirinya sendiri. Memperlakukan sesama manusia sebagai subjek seperti dirinya sendiri adalah cara yang diharapkan dan diajarkan oleh Tuhan Yesus, yang dikenal dengan sebutan Hukum Kasih.

Kata $\sigma \pi \lambda \alpha \gamma \chi \nu \iota \zeta o \mu \alpha \iota$ ini merupakan kata yang mendeskripsikan karakter Mesianik karena kata ini menggambarkan sifat-sifat Mesias yang mengasihi, menyayangi, bahkan rela berkorban untuk menolong umat manusia, begitu juga sikap dari orang Samaria ketika menolong orang yang terluka, ia mau atau rela berkorban untuk melakukan pertolongan pada orang tersebut. Sikap seperti ini dikarenakan memandang manusia sebagai subyek, menghargai bukan hanya sebagai sesuatu objek saja, tidak berburuk sangka dan senantiasa mau menolong sesama.

Pelayanan yang memandang manusia sebagai subyek adalah fondasi yang penting bagi perilaku antar manusia, karena manusia diciptakan untuk saling menghargai, menolong, menguatkan. Perilaku yang memperlakukan manusia hanya sebagai objek mengakibatkan kesengsaraan dalam kehidupan manusia di bumi ini. Tuhan Yesus memberikan cara yang tepat jangan pernah menganggap manusia hanya sebagai objek semata, hal tersebut sangat berbahaya, penderitaan, peperangan yang terjadi di muka bumi ini karena kurang menghargai sesamanya dengan baik.

\section{Pelayanan yang Proaktif (ayat 33)}

Masih dalam ayat ke-33 dari kata $\varepsilon ı \omega \omega$ yang secara harfiah berarti melihat, tergambarlan suatu pelayanan proaktif karena kata $\varepsilon ı \omega$ ini memiliki pengertian yang sangat luas karena mengandung pengertian mengarahkan mata, memberikan 
perhatian, mengarahkan pikirannya, melakukan observasi, melakukan infeksi/penyelidikan yang dalam, melakukan interview dan melakukan kunjungan.

Kata $\varepsilon เ \delta \omega$ inipun mengandung pengertian berusaha mengenali, mengetahui, mempelajari, memahami, mencari pengertian yang dalam, mendalami, ingin memahami fakta yang terjadi.

Itulah yang dinamakan sikap proaktif, sikap yang inisiatif, tidak perlu menunggu perintah seseorang, sikap yang digerakkan dari dalam hatinya sendiri, sikap yang terpuji, sikap yang mandiri, tidak mau mengandalkan orang lain. Namun sikap ini bukan sembarangan, sikap ini penuh kehati-hatian dengan memperhatikan, menyelidiki, mengamati dengan cermat.

Sikap proaktif inilah yang dilengkapi dengan kata $\sigma \pi \lambda \alpha \gamma \chi \nu \iota \zeta o \mu \alpha \iota$ yaitu digerakkan oleh belas kasihan, kata "digerakkan" menggambarkan sikap yang proaktif, penuh inisiatif, kreatifitas, mandiri, tekun dan tidak perlu harus menunggu perintah atau bantuan dari orang lain.

Pelayanan proaktif terjadi karena adanya gerakan berbelas kasihan, memperlakukan sesama sebagai subyek sehingga mengeluarkan tindakan yang semangat, penuh inisiatif dan inovatif. Semua itu dilakukan karena tindakan kasih, menyayangi sesamanya, itulah yang dikemukakan dalam Hukum Kasih yang dinyatakan oleh Tuhan Yesus.

\section{Pelayanan Holistik (ayat 34)}

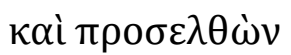

dan ia datang mendekati

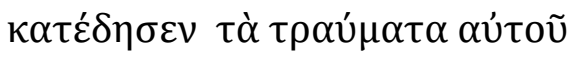

untuk membalut luka-luka dengan inisiatifnya sendiri

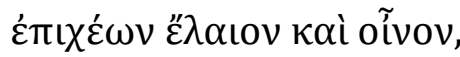

lalu menyiraminya dengan minyak zaitu dan anggur miliknya sendiri

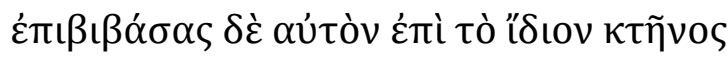

menolong orang tersebut naik ke atas binatang tunggangan miliknya sendiri

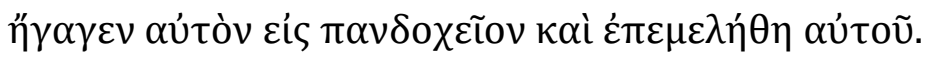


membawa orang tersebut ke tempat penginapan untuk menjalani perawatan

Dalam ayat ini, terdapat empat kata kerja yang menunjukkan partisipasi aktif dari orang Samaria dalam menolong orang yang terluka tersebut, sebagai sambungan dari sikap proktif di dalam ayat 33. Kata kerja yang pertama adalah $\pi \rho о \sigma \varepsilon \lambda \theta \grave{\omega} \nu$ aorist aktif partisif yang artinya datang, atau mengadakan pendekatan dalam rangka melakukan dua kegiatan yaitu kata kerja kedua $\kappa \alpha \tau \varepsilon \dot{\delta} \eta \sigma \varepsilon v$ aorist aktif indikatif, artinya membalut/mengikat, dan kata kerja ketiga $\dot{\pi} \pi \iota x \dot{\varepsilon} \omega v$ present aktif partisip, artinya menuangkan ke atas luka tersebut yaitu minyak zaitun untuk mengurangi rasa sakit dan menuangkan anggur agar luka tersebut tidak mengalami infeksi berlanjut.

Artinya orang Samaria datang untuk melakukan pendekatan atau perkenalan karena orang yang terluka tersebut adalah orang Yahudi yang merupakan musuh dari orang Samaria, berlawanan dengan tindakan pada umumnya ketika berhadapan dengan musuhnya. Orang Samaria tersebut justru melakukan tindakan yang terpuji yaitu membalut dan merawat luka dan juga

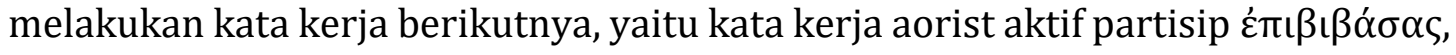
yang artinya untuk menempatkan sesuatu ke atas. Artinya orang Samaria itu menempatkan orang terluka tersebut ke atas binatang tunggangan yaitu keledai untuk dibawa ke tempat penginapan agar mengalami perawatan lebih lanjut.

Bukan hanya disitu saja kata kerja berikutnya adalah kata kerja yang penting juga yaitu kata kerja $\varepsilon ́ \pi \varepsilon \mu \varepsilon \lambda \eta ́ \theta \eta$ yang artinya merawat, mengurus, dan memelihara orang terluka tersebut dengan baik dan intensif di tempat penginapan. Inilah tindakan yang sangat terpuji di mana musuhnya dirawat dengan penuh dengan kasih yang totalitas sebagai kelanjutan dari pelayanan holistik.

Terjemahan untuk ayat ini adalah: Lalu orang Samaria itu datang, mendekat dan berkenalan kepada orang itu, lalu membalut luka-lukanya, mengoleskan dengan minyak zaitun untuk menghilangkan rasa sakit dan menuangkan anggur ke atas tubuhnya untuk mencegah terjadinya infeksi lanjut, lalu membantu orang tersebut naik ke atas binatang tunggangan kepunyaannya sendiri, lalu membawanya ke tempat penginapan untuk melakukan perawatan 
lebih lanjut dan efektif serta untuk mengurus semua kebutuhan yang diperlukannya.

Tindakan yang dilakukan oleh orang Samaria seperti yang dijlelaskan di atas adalah tindakan yang holistik, tindakan yang menyeluruh, tindakan yang sistematis, setelah melihat dan mengenali kebutuhan yang diperlukan orang Samaria tersebut melakukan tindakan membalut, merawat, membawa untuk menginapkannya adalah tindakan holistik.

Dia melihat kebutuhan yang diperlukan adalah pertolongan untuk memulihkan fisik dan mentalnya, tentunya selain fisik yang terluka, mentalnya/psikisnya mengalami "down" karena serangan dari penyamun. Pertolongan perlu dilakukan secara holistik dengan memperhatikan kebutuhan pemulihan fisik, merawatnya secara intensif di dalam penginapan agar dapat fokus beristirahat dengan baik di dalam ruangan penginapan, serta juga dicukupkan kebutuhan biaya/pendanaannya. Berbagai tindakan ini adalah tindakan secara holistik atau menyeluruh karena menyentuh semua aspek seperti tubuh fisiknya, mental/jiwanya, ekonominya juga.

\section{Pelayanan Penuh Totalitas (ayat 35)}

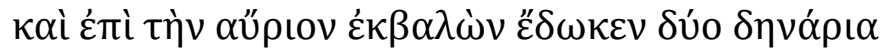

dan orang Samaria itu memberikan uang dua dinar

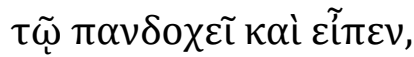

kepada pemilik penginapan serta berkata kepada pemilik penginapan tersebut

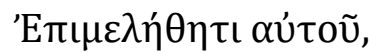

untuk merawatnya lebih lanjut

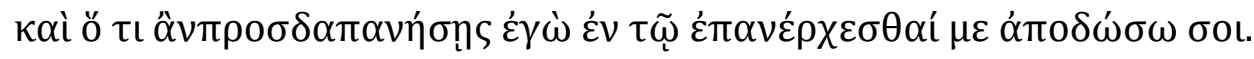

dan saya akan bertanggung-jawab atas semua biaya lain yang diperlukan apabila terjadi kekurangan biaya perawatan saat saya kembali lagi nanti. 
Pada ayat ini, orang Samaria kembali berinisiatif penuh totalitas untuk memberi bantuan selanjutnya yang lebih excellent, yaitu dengan memberikan bantuan atau dukungan pembiayaan atau pendananan, hal ini terlihat dari kata kata kerja $\varepsilon \delta \omega \kappa \varepsilon v$ aorist aktif indikatif berarti memberikan sesuatu yaitu dua keping perak kepada pemilik penginapan. Dua keping perak atau dinar tersebut sama dengan upah dua hari kerja pada waktu itu, pemberian dana tersebut dalam rangka memberikan uang muka agar pemilik penginapan tidak direpotkan karena orang Samaria akan pergi dulu dari tempat penginapan karena harus melakukan kegiatan atau aktifitas pekerjaan sehari-hari.

Lalu ada kata perintah 'E $\pi \mu \varepsilon \lambda \eta ́ \theta \eta \tau$ yang artinya sama dengan ayat sebelumnya agar dirawat, diurus semua kebutuhan bagi orang terluka tersebut, dan

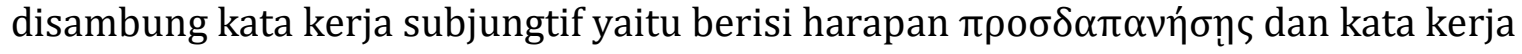

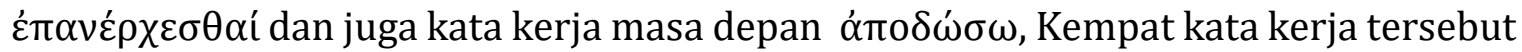
menjelaskan tentang pertanggung-jawaban orang Samaria untuk mencukupi semua biaya perawatan yang dilakukan, karena Orang Samaria tersebut harus meninggalkan orang terluka tersebut di penginapan, karena ia harus bekerja. Orang Samaria menjamin semuanya saat dia kembali ke penginapan, sehingga saat ditinggalkan kepada pemilik penginapan tidak perlu kuatir akan semua yang diperlukan, yang terpenting adalah orang tersebut dapat sembuh dan pulih dari luka-lukanya..

Jadi terjemahan ayat ini adalah sebagai berikut keesokan harinya orang Samaria itu menyerahkan dua keping perak kepada pemilik penginapan, seraya meminta permohonan kepada pemilik penginapan tersebut untuk merawat lebih lanjut, dan mengurus semua keperluan yang dibutuhkan oleh orang yang menderita luka-luka ini, dan berjanji kepadanya bahwa ia akan kembali dan bertanggung-jawab untuk membayar semua kebutuhan yang dierplukan apabila dirasakan masih kurang, agar orang tersebut dapat disembuhkan atau dipulihkan.

Pelayanan penuh totalitas adalah pelayanan yang lengkap, paripurna, utuh, bahkan pelayanan yang menuju harapan kesempurnaan, yang tak lain bertujuan membuat sejahtera dan makmur sesama manusia. Pelayanan ini adalah pelayanan yang merupakan kelanjutan dari perlakuan memandang manusia sebagai subyek, pelayanan proaktif, pelayanan holistik. Pelayanan totalitas adalah pelayanan yang 
tuntas mulai dari awal sampai akhir, dan bahkan ada pelayan lanjutan setelah proses akhir.

Pelayanan totalitas adalah cerminan dari karakter Kristus, teladan Kristus yang melayani secara totalitas dari awal sampai akhir juga dinyatakan Alkitab ketika Tuhan Yesus berkata menjelang ajalnya di kayu Salib: "sudah selesai”. Pelayanan totalitas dari Orang Samaria adalah menyelesaikan semua yang diperlukan tanpa meninggalkan hutang atau masalah di kemudian hari. Pelayanan totalitas adalah pelayanan sampai akhir atau sampai tuntas, lengkap, utuh tanpa meninggalkan satupun keluhan atau kekurangan.

\section{Pelayanan Sinergitas Antara Allah dan Manusia (ayat 33-35)}

Dalam teks Lukas 10:33-35 ini memang tidak dijelaskan lebih lanjut tentang apakah terjadi kesembuhan setelah mengalami pelayanan perawatan yang dilakukan oleh orang Samaria tersebut. Hal ini menjelaskan bahwa faktor kesembuhan bukanlah ranah manusia, melainkan atas ijin atau kehendak dari Tuhan.

Tugas manusia seperti yang dijelaskan dalam beberapa kata kerja dalam ayatayat ini, $\quad \kappa \alpha \tau \alpha \delta \varepsilon \omega \quad \tau \rho \alpha u \mu \alpha$ artinya membalut luka-luka, $\varepsilon \pi \iota \chi \varepsilon \omega$ artinya menyirami/mengolesi, $\varepsilon \pi \iota \mu \varepsilon \lambda \varepsilon o \mu \alpha \iota$ artinya merawat, adalah tugas-tugas yang dilakukan oleh manusia untuk mengharapkan terjadinya pemulihan. Juga kata-kata membawa ke tempat penginapan, penyediaan biaya penginapan adalah tugas-tugas manusia, sambil terus mengharapkan kesembuhan yang dari Tuhan.

Kata $\sigma \pi \lambda \alpha \gamma \chi \nu \iota \zeta o \mu \alpha \iota$ yang berarti tergeraklah hatinya oleh belas kasihan mengandung pengertian kerjasama (sinergitas) antara manusia yang hatinya mau digerakkan oleh belas kasihan, ketika hatinya tergerak oleh belas kasihan sehingga melakukan tindakan membalut, mengolesi, merawat, membiayai maka perkenanan Tuhan akan terjadi dan kesembuhan atau pemulihan yang diharapkan akan terjadi pula.

Pelayanan yang melibatkan Allah dalam segala usaha manusia adalah pelayanan yang terjadi dalam teks ini. Dimulai dari Allah yang menggerakkan hati manusia agar dipenuhi belas kasihan, lalu manusia meresponnya dengan melakukan 
tindakan melihat, menolong, memnalut luka, mengolesi luka, merawat, menginapkan, membayari lalu seraya berharap kesembuhan yang dari Allah bisa nyata.

Dari Kata $\kappa \alpha \tau \alpha \delta \varepsilon \omega \tau \rho \alpha u \mu \alpha$ yang berarti mebalut dan $\varepsilon \pi \iota \mu \varepsilon \lambda \varepsilon \circ \mu \alpha \iota$ yang berarti merawat adalah bentuk usaha manusia seperti pengobatan dan dengan peran Allah, manusia dapat mewujudkan pemulihan, penyembuhan dan kesejahteraan. Pelayanan yang melibatkan Allah atau pelayanan kerjasama antara Allah dan manusia ini, tentunya akan menghasilkan pelayanan yang sangat baik atau excellent, karena pelayanan ini sangat memuaskan dan setiap orang yang meihatnya akan memuliakan Allah.

\section{Rancang Bangun atau Model Pelayanan Pastoral Konseling Terhadap Pasien Berdasarkan Lukas 10:33-35}

Berdasarkan hasil eksegesa teks Lukas 10:33-37 di atas, maka dihasilkan prinsipprinsip pelayanan pastoral, maka disusunlah beberapa model pastoral terhadap pasien rawat inap berdasarkan Lukas 10:25-37 yang adalah sebagai berikut:

\section{Model Pelayanan yang Memandang Pasien Sebagai Subjek}

Dalam pelayanan terhadap pasien para pelayan kesehatan harus memandang pasien bukan sebagai objek, justru subjek. Mengapa demikian? Karena baik para pelayan maupun yang dilayani adalah subjek, adalah manusia yang saling membutuhkan, perjumpaan antara mereka adalah perjumpamaan timbal balik dimana pasien membutuhkan pelayanan kesehatan. Tetapi bisa saja suatu ketika ketika kitapun sakit, pastilah kita pun membutuhkan pertolongan dari orang lain.

Memandang pasien hanya sebagai objek akan berakibat buruk, karena justru kita memanfaatkan keadaan pasien yang lemah untuk kepentingan diri kita sendiri, hal ini tidak boleh dilakukan. Seperti contoh penyimpangan pelayanan kesehatan yang dijelaskan oleh peneliti di dalam bab satu, pasien dijadikan alat pemenuhan ekonomi, praktek seperti tersebut tentunya dilarang untuk dilakukan. Pada intinya pasien bukan objek, melainkan subjek seperti kita semua, hal inilah yang disebut sesama manusia, dimana hakekat manusia adalah makhluk yang 
mulia, independen, namun diciptakan untuk saling bekerja sama, saling memperdulikan, saling mengasihi, sehingga diharapkan tercipta kedamaian.

Seperti yang dijelaskan dalam teks Lukas 10:33-35 di atas memperlakukan manusia sebagai subyek akan mengakibatkan dampak positif bagi mereka atau bagi pasien, tindakan perawatan kesehatan akan menjadi maksimal, namun sebaliknya apabila memandang pasien hanya sebagai objek pemenuhan kebutuhan hidup para pelayan kesehatan, maka akan berakibat buruknya pelayanan kesehatan yang dilakukan.

\section{Model Pelayanan yang Proaktif}

Model pelayanan proaktif adalah model pelayanan yang penuh inisiatif, kreatif, inovatif dan terus-menerus dikembangkan sesuai kebutuhan pasien dan sesuai zamannya di mana dalam era pelayanan kesehatan modern, alat-alat kesehatan yang canggih berbasih teknologi informasi dan komunikasi dimanfaatkan dengan sebaik-baiknya bagi kesembuhan pasien.

Pelayanan yang cepat, tanggap, ramah, modern adalah hasil dari model pelayanan proaktif, tidak ada lagi para pelayan kesehatan yang malas, kurang tanggap, menunggu perintah atasan dan lain sebagainya. Model pelayanan proaktif ini terjadi saat para pelayan kesehatan hatinya digerakkan oleh belas kasihan.

\section{Model Pelayanan Totalitas}

Model pelayanan totalitas adalah pelayanan komprehensif, tersistem dengan baik, pelayana yang utuh mulai dari awal sampai akhir. Model pelayanan yang lengkap.

Di dalam teks Lukas 10:33-35 seperti telah dijelaskan bahwa pelayanan totalitas dimulai dari awal ketika ada niat baik, motivasi yang baik untuk menolong sesame manusia, atau menolong pasien. Lalu pasien dibalut lukanya, diolesi dengan minyak, dituangkan anggur, lalu membawanya ke tempat 
penginapan, mendampingi pasien untuk dirawat. Lalu membiayai semua kebutuhan perawatan.

Bukan hanya di situ saja, apabila ada kekurangan-kekurangan lain maka semua kebutuhan akan dicukupi. Itulah pelayanan totalitas yang saat ini bisa diterapkan untuk pelayanan pasien yaitu melayani pasien mulai dari awal datang ke rumah sakit, proses pendaftaran, bertemu dengan dokter, penggunaan alat kesehatan, pemberian obat, penggunaan fasilitas, perawatan yang dilakukan oleh tenaga paramedis, sampai pasien pulang dari rumah sakit, dan bahkan pelayan pasca atau lanjutan seperti kontrol ke dokter dan pelayanan pembiayaan kesehatan yang baik lancar harusnya menjadi dijalankan dengan massif dan tersistem/terpola sehingga menjadi pelayanan yang totalitas. Itulah yang dimaksud model pelayanan totalitas.

\section{Model Pelayanan Holistik}

Dari hasil eksegesa di atas jelas terlihat pelayanan holistik dan totalitas dari orang Samaria yang murah hati. Pelayanan Holistik berasal dari dua kata yaitu wholeness dan holiness. Kata holiness berasal dari kata holy atau kudus/suci. Kata "kudus" di dalam Alkitab berarti dipisahkan, artinya dipisahkan untuk dari dosa untuk mengalami kekudusan dan kesembuhan. Kekudusan dan kesembuhan menjadi suatu paket yang tidak dapat dipisahkan, hal ini terlihat dalam contohcontoh di Alkitab.

Kekudusan dan kesembuhan berkaitan erat hal ini dialami Yesaya, dalam pemanggilan sebagai nabi, dimna perlu pengudusan dalam hidupnya. Juga dialami Petrus yang awalnya penakut sehingga menyangkal Yesus sebanyak tiga kali, namun melalui kebangkitan Yesus terjadi perubahan dalam dirinya, terjadi pengudusan dan pemulihan, penyembuhan sehingga Petrus menjadi pelayan Tuhan yang sangat pemberani, setia, sampai akhir hayat, pernah dimasukkan penjara ia tidak gentar sedikitpun, bahkan matinya pun rela di salib terbalik. ${ }^{75}$ 
Juga pengalaman Saul dari Tarsus, ketika mengalami perjumpamaan dengan Tuhan Yesus yang bangkit dari kubur di jalan menuju Damaskus, ia yang tadinya mengalami kebutaan di sembuhkan oleh Tuhan. ${ }^{76}$ Dari ketiga contoh di atas juga nampak bahwa untuk memenuhi panggilan Tuhan yang kudus, mereka harus menyerahkan diri mereka secara utuh/keseluruhan hidup mereka. Jadi holistik itu menyerahkan diri sepenuhnya untuk disucikan oleh Tuhan maka akan terjadi pemulihan, penyembuhan.

Pelayanan holistik yang berasal dari kata wholeness mengisyaratkan perlunya pelayanan yang terpadu, yang utuh, yang melibatkan semua aspek dalam hidup manusia, mulai dari kebutuhan fisik, psikis, ekonomi, sosial, dan lain-lain bahkan kebutuhan yang paling penting adalah kebutuhanspiritualnya, seperti yang dijelaskan di atas kekudusan berhubungan erat dengan kesembuhan karena kekudusan adalah hasil pertemuan manusia dengan Allah.

Implikasi pelayanan holistik dalam Pastoral terhadap pasien rawat inap berdasarkan Lukas 10:33-35, ini adalah harus dilakukan dengan sungguhsungguh (holiness), dan terpadu (wholeness), serta totalitas, yaitu sebagai berikut:

Pertama, pelayan pastoral harus melihat dengan mata kepala sendiri akan kebutuhan pasien, mata yang melihat ke arah pasien bukanlah hanya mata fisik tapi mata hati kita yang penuh dengan belas kasihan, setelah melihat orang sakit tersebut, para pelayan pastoral melakukan perkenalan yang baik, ramah agar menumbuhkan kepercayaan terhadap orang sakit tersebut, bahwa mereka berniat akan menolongnya. Serta pihak pasien mau terbuka terhadap bantuan pertolongan kita, karena kalau terpaksa maka proses pemyembuhan tidak akan berjalan dengan baik.

Ketiga, karena melihat kebutuhan orang yang sakit maka kita harus memiliki keinginan seolah-olah kita ingin memindahkan hati kita kepada orang sakit tersebut. Hal ini menggambarkan rasa peduli yang dalam, rasa penuh kasih 
sayang yang terdalam, yang sering disebut compassion atau memiliki rasa belas kasih. ${ }^{77}$

Keempat, melakukan pertolongan pertama atau pertolongan dasar pada orang sakit, agar mengurangi rasa sakitnya sebelum perawatan yang lebih intensif. Pertolongan tersebut adalah membalut luka, mengolesi dengan minyak, menuangi dengan anggur. Hal ini adalah pertolongan pertama pada orang sakit, sebelum di bawa kepada perawatan tingkat lanjut.

Kelima, menyediakan alat transportasi untuk dilakukan perawatan lebih lanjut yaitu perawatan inap, karena perlu waktu dan tempat atau ruang perawatan yang baik, yang representatif untuk melakukan recovery atau pemulihan secara maksimal.

Keenam, selama menjalani proses rawat inap tentunya diperlu pendampingan atau konseling terhadap orang sakit tersebut, karena orang sakit biasanya membutuhkan teman untuk mendampingi, dikarenakan aktifitasnya menjadi terbatas dan pastilah ia membutuhkan pertolongan untuk melakukan aktifitasnya seperti makan, minum, mandi, buang air dan sebagainya.

Ketujuh, karena perawatan di ruang rawat inap membutuhkan sarana prasarana, maka perlu disediakan biaya untuk pengadaan obat, dan bahan-bahan lain yang diperlukan bagi perawatan tersebut, oleh karena itu, yang kedelapan, perlu ada orang yang mau bertanggung-jawab untuk menanggung semua beban secara keseluruhan dan orang yang mau memberikan pelayanan kesehatan secara totalitas.

77 Compassion berasal dari kata "com" yang artinya " Together" = bersama dan "passion" yang artinya Suffering = penderitaan. Sehingga "Compassion" dapat diartikan dengan : kita terhubung dengan rasa sakit orang lain (empati), kita datang untuk mengetahui apa penderitaan yang dirasakan orang lain Dan melakukan sesuatu sbb:

- tetap berada didekatnya Dan berbagi hal baik diwaktu yang tepat.

- membantu orang lain untuk meraih yang diinginkan

- menyatu dengan compassion berarti kita sedang berusaha menjadi seorang manusia seutuhnya HUMAN : Help - Unselfishly - Meet - Another's - Need "Membantu apa yang dibutuhkan orang lain tanpa kepentingan pribadi;" internet; diambil dari http://lucidashram.com/2017/02/04/compassion/; diakses 07 Desember 2017 


\section{Model Pelayanan Sinergitas/Kerjasama Antara Manusia dan Tuhan}

Maksudnya pelayanan ini adalah segala usaha yang dilakukan manusia haruslah seijin dari Tuhan. Kesembuhan adalah otoritas dari Tuhan, manusia boleh mengusahakannya, namun mengenai hasilnya harus diserahkan pada Tuhan.

Manusia dalam hal ini para pelayan medis dan paramedic di rumah sakit perlu mengupayakan semua sumber dayanya, baik mengerahkan ilmu pengetahuannya, pemanfaatan teknologi kesehatan seperi menghadirkan alatalat kesehatan modern, memberikan fasilitas kesehatan yang terbaik, membuat sistem pelayanan yang terbaik, menyediakan sistem pembiayaan kesehatan yang terbaik.

Namun setelah itu melibatkan Tuhan dalam doa dan harapan agar kesembuhan bisa terjadi terhadap para pasien yang dirawat. Salah satu pemanfaatan ilmu pengetahuan adalah ilmu psikologi pasien, dalam melayani pasien perlu melihat aspek-aspek psikologisnya seperti yang pernah diungkapkan oleh Dr. Elisabeth Kübler-Ross pada bukunya tahun 1969, On Death and Dying, memperkenalkan Lima Tahapan Kedukaan (The Five Stages of Grief).

Tahapan-tahapan, yang lebih dikenal dengan singkatannya dalam bentuk DABDA, dengan penjelasan sebagai berikut:

Penyangkalan (Denial) — "Saya merasa baik-baik saja."; "Hal ini tidak mungkin terjadi, tidak pada saya."Penyangkalan biasanya merupakan pertahanan sementara untuk diri sendiri. Perasaan ini pada umumnya akan digantikan dengan kesadaran yang mendalam akan kepemilikan dan individu yang ditinggalkan setelah kematian..

Marah (Anger) — "Kenapa saya ? Ini tidak adil!"; "Bagaimana mungkin hal ini dapat terjadi pada saya?"; "Siapa yang harus dipersalahkan?"Ketika berada pada tahapan kedua, individu akan menyadari bahwa ia tidak dapat senantiasa menyangkal. Oleh karena kemarahan, orang tersebut akan sangat sulit untuk diperhatikan oleh karena perasaan marah dan iri hati yang tertukar.

Menawar (Bargaining) - "Biarkan saya hidup untuk melihat anak saya diwisuda."; "Saya akan melakukan apapun untuk beberapa tahun."; "Saya akan memberikan simpanan saya jika..."Tahapan ketiga melibatkan harapan supaya individu dapat sedemikian rupa menghambat atau menunda kematian. Biasanya, 
kesepakatan untuk perpanjangan hidup dibuat kepada kekuasaan yang lebih tinggi dalam bentuk pertukaran atas gaya hidup yang berubah. Secara psikologis, individu mengatakan, "Saya mengerti saya akan mati, tetapi jika saja saya memiliki lebih banyak waktu..."

Depresi (Depression) - "Saya sangat sedih, mengapa perduli dengan lainnya?"; "Saya akan mati .. Apa keuntungannya?"; "Saya merindukan orang saya cintai, mengapa melanjutkan?"Pada tahapan keempat, penderita yang sekarang, menolak dibesuk dan menghabiskan banyak waktu untuk menangis dan berduka. Proses ini memberikan kesempatan kepada pasien yang sekarat untuk memutus hubungan dengan sesuatu yang dicintai ataupun disayangi. Tidak disarankan untuk mencoba menghibur individu yang berada pada tahapan ini. Ini merupakan waktu penting untuk berduka yang harus dilalui.

Penerimaan (Acceptance) — "Semuanya akan baik-baik saja."; "Saya tidak dapat melawannya, Saya sebaiknya bersiap untuk hal itu."Ini merupakan tahapan terakhir, individu tiba pada kondisi sebagai mahluk hidup atau kepada yang dicintainya. ${ }^{78}$

Artinya ketika seorang pasien bisa memasuki tahap penerimaan atau acceptance, walaupun ia menghadapi hasil perawatan yang tidak sesuai dengan harapannya, misalnya pada penderita penyakit kanker, maka justru proses pemulihan sejati akan terjadi padanya. Inilah yang dinamakan misteri ilahi, hasil akhir dari sebuah perawatan belum tentu menghasilkan kesembuhan, malah justru kadang sebaliknya bisa saja lebih parah penderitaan sakitnya, atau bahkan mengakibatkan kematian.

Itulah yang dinamakan model pelayanan yang mau bekerjasama melibatkan keilahian Tuhan atau otoritas Tuhan. Manusia tidak boleh memaksakan kehendaknya, karena otoritas, termasuk otoritas penyembuhan penyakit hanyalah milik Tuhan semata. Manusia perlu melakukan usaha yang terbaik dan maksimal, namun perlu melibatkan Tuhan, atau terus-menerus mau bekerja-sama dengan Tuhan karena Tuhan akan memberikan yang terbaik.

\footnotetext{
${ }^{78}$ Internet; diambil dari: https://id.wikipedia.org/wiki/Model_Kübler-Ross; diakses 04 Desember 2017.
} 


\section{Penutup}

Pelayanan konseling pastoral adalah pelayanan yang mendukung kesembuhan bagi pasien terutama yang menjalani perawatan kesehatan di rumah-rumah sakit, terutama bisa dikolaborasikan dengan pelayanan yang dilakukan oleh para tenaga medis seperti para dokter, perawat, dan tenaga- tenaga medis lainnya. Kelebihan dari pelayanan pastoral konseling adalah adanya gabungan antara kebutuhan psikis dan spiritual dari para pasien; pelayanan ini memperlengkapi pelayanan yang diberikan tenaga-tenaga medis sehingga bisa melihat manusia secara utuh dan lengkap atau holistik. Dari hasil kolaborasi ini akan membuat para pasien lebih memahami makna sakit dan penyakit, dan juga makna kehidupan keseluruhan, sehingga para pasien tersebut memahami makna kesembuhan sejati justru bukan hanya dari sudut pandang manusia, melainkan memandangnya dari sudut pandang Tuhan Sang Pencipta yang selalu merencanakan kebaikan dan kesejahteraan bagi setiap manusia.

\section{Biografi Singkat}

Pendidikan terakhir penulis adalah menyelesaikan S3 di Institut Injil Indonesia (I-3) Kota Batu, Jawa Timur: Tamat tahun 2018. Pelayanan antara lain: Penggembalaan di Gereja Baptis Indonesia Wanamukti Semarang dari tahun 2000 - 2006; Penggembalaan di Gereja Baptis Indonesia Cabang Gubeng, Malang, Jawa Timur, 2008 - 2014; Dosen di STT Baptis Indonesia (STBI) Semarang, Jawa Tengah, dari tahun 2002 - 2008. Dan hingga kini sebagai konselor Pastoral di Rumah Sakit Baptis Batu, Jawa Timur, sejak 2008 hingga sekarang, dan juga Dosen Pasca Sarjana di STT Satyabhakti-Malang, Jawa Timur, dari tahun 2018 hingga sekarang. Penulis menggunakan pendekatan psikospiritual dalam pelayanan pastoral konseling.

Email: sortjansim@yahoo.com 